\title{
WHY MODEST PROPOSALS OFFER THE BEST SOLUTION FOR COMBATING RACIAL PROFILING
}

\begin{abstract}
SEAN P. TRENDE
There is nothing more painful to me at this stage in my life than to walk down the street and hear footsteps and start thinking about robbery ... [and] [t]hen look around and see somebody white and feel relieved.
\end{abstract}

\section{Reverend Jesse Jackson ${ }^{1}$}

The average man doesn't want to be free.... He simply wants to be safe.

H.L. Mencken ${ }^{2}$

\section{INTRODUCTION}

About the only thing on which the parties agree is this: In August of 1998, Sergeant First Class Rossano V. Gerald, accompanied by his twelve-year-old son Gregory, drove his red Nissan 300ZX across the Oklahoma border, was stopped twice by police officers, and was searched once. ${ }^{3}$ Apart from these basic facts, however, the parties agree on very little. According to the plaintiffs, Gerald and his son were forced to sit in a sweltering squad car while officers ransacked their automobile for two hours. The plaintiffs further maintain that

Copyright $(\mathcal{2} 2000$ by Sean P. Trende.

1. Jesse Jackson, Speech at Operation PUSH Headquarters (Nov. 27, 1993), quoted in Mary A. Johnson, Crime: New Frontier-Jesse Jackson Calls It Top Civil-Rights Issue, CHI. Sun-Times, Nov. 29, 1993, at 4.

2. Wendy Kaminer, Taking Liberties: The New Assault on Freedom, AM. ProsPeCt, Jan. 1, 1999, at 33, 40 (quoting H.L. Mencken).

3. See First Amended Complaint and Jury Demand at 6-7, Gerald v. Department of Pub. Safety (W.D. Okla. May 18, 1999) (No. CIV 99-676-R); Brief in Support of Motion to Dismiss by the Individual Defendants at 2, Gerald (No. CIV 99-676-R); Kevin Johnson, Okla. Commissioner Denies Bias Alleged by ACLU, USA TODAY, May 20, 1999, at A3 (stating that Gerald and his son were "stopped and detained"). 
this stop and search occurred simply because Gerald and his son are black. ${ }^{4}$ The defendants, ${ }^{5}$ on the other hand, maintain that during the course of the stop, the state troopers developed a reasonable and articulable suspicion that Gerald was attempting to transport drugs into the state, which justified the detention and the ensuing search. ${ }^{6}$

Gerald's case is not unique. Indeed, in the last two years, allegations of officers using race as part of their decision to stop or detain a suspect, a practice commonly known as racial profiling, have drawn increased attention in the press, ${ }^{7}$ in scholarly journals, ${ }^{8}$ and in the courts. ${ }^{9}$ Even President Clinton has weighed in on the debate. ${ }^{10}$ Most

4. See First Amended Complaint at 16-17, Gerald (No. CIV 99-676-R).

5. Gerald named the Chief Officer of the Department of Public Safety, the Commissioner of Public Safety, the Oklahoma Department of Public Safety, the Chief of the Highway Patrol Division, and four officers allegedly involved in the search. See id. at 3-6.

6. See Brief in Support of Motion to Dismiss by the Individual Defendants at 2, Gerald (No. CIV 99-676-R).

7. See, e.g., Boca Raton Cops Deny Racial Profiling, Fla. TODAY, July 29, 1999, at B5 (alleging racial profiling in the detention of a black man asked for identification in a parking lot); Black America in Uproar Over Police Brutality, JET, June 28, 1999, at 4, 6 (cataloging various national examples of police brutality and racial profiling); ACLU: ACLU Launches Special Web Collection on Racial Profiling and Driving While Black, M2 PRESSWIRE, June 10, 1999, available in 1999 WL 19097084 [hereinafter ACLU Launches Special Web Collection] (describing an ACLU campaign to eradicate racial profiling).

8. See, e.g., Angela J. Davis, Race, Cops, and Traffic Stops, 51 U. Miami L. ReV. 425, 427 (1997) (discussing "discriminatory pretextual traffic stops"); David A. Harris, "Driving While Black" and All Other Traffic Offenses: The Supreme Court and Pretextual Traffic Stops, 87 J. CRIM. L. \& CRIMINOLOGY 544, 546 (1999) ("[I]f past practice is any indication, [the police] will use the traffic code to stop a hugely disproportionate number of African-Americans and Hispanics."); Tracey Maclin, Race and the Fourth Amendment, 51 VAND. L. REV. 333, 336 (1998) ("[P]olice departments across the nation ... continue to target blacks in a manner reminiscent of the slave patrols of colonial America."); Katheryn K. Russell, "Driving While Black": Corollary Phenomena and Collateral Consequences, 40 B.C. L. REV. 717, 717 (1999) (describing the "wide range of race-based suspicion of Black and Brown motorists" known as "Driving While Black"'); Omar Saleem, The Age of Unreason: The Impact of Reasonableness, Increased Police Force, and Colorblindness on Terry "Stop and Frisk," 50 OKLA. L. REV. 451, 453 (1997) (arguing that the Terry "stop and frisk" standard is "particularly inappropriate for Black Americans"); L. Darnell Weeden, It Is Not Right Under the Constitution to Stop and Frisk Minority People Because They Don't Look Right, 21 U. ARK. LiTTLE Rock L.J., 829, 829 (1999) (explaining why routine detention should not be a reasonable seizure of a person where race may be an unarticulated factor).

9. See, e.g., Hodgers-Durgin v. De La Vina, 199 F.3d 1037, 1038 (9th Cir. 1999) (denying a class action suit brought by motorists stopped by Border Patrol agents); National Congress for Puerto Rican Rights v. City of New York, 191 F.R.D. 52, 53-54 (S.D.N.Y. 1999) (reinstating the plaintiff's claim that members of the New York City Police Department stopped citizens based only on race); United States v. Stone, 73 F. Supp. 2d 441, 447 (S.D.N.Y. 1999) (reviewing whether race was the critical factor behind a Terry stop).

10. See William J. Clinton, The President's Radio Address (Mar. 13, 1999), in ADMINISTRATION OF WILLIAM JEFFERSON CLINTON, 1999, at 428, 429 ("I have been deeply disturbed by recent allegations of serious police misconduct and continued reports of racial profiling...."). 
commentary on the practice has consisted of fierce criticism from the Left, although a few observers on the Right have condemned profiling as well. ${ }^{11}$ Few commentators have defended the technique. ${ }^{12}$

This Note attempts to strike a middle ground between unreserved condemnation of profiling and defending the basically indefensible. It pays some deference to the justifications cited by defenders of the practice: that there probably is some rational basis for profiling and that combating profiling may well impede anti-crime efforts. However, the Note also strongly condemns the practice as antithetical to modern American ideals of fairness and equality. Rather than completely favoring one set of considerations over the other, as most commentators have done, this Note endeavors to find an acceptable solution that accords appropriate weight to each set of concerns.

Part I supplies a brief sketch of background information before exploring the legal context surrounding the issue. It provides an overview of the history of racial profiling in America ${ }^{13}$ and examines why,

11. See, e.g., Chapin Rose, U. Illinois: Column: Civil Rights Should Not Be Arbitrary, UWIRE, Jan. 20, 1999, available in 1999 WL 5935138 ("Actually, I am a Republican who is increasingly fearful of governmental bureaucracy's slow transition into Big Brother. . . Jackbooted police tactics must not and cannot be tolerated in a free society."); Stuart Taylor Jr., $R a$ cial Profiling: The Liberals Are Right, NAT'L J., Apr. 24, 1999, at 1084, 1084 (contending that racial profiling poisons race relations and hands an issue for "opportunists" such as the Rev. Al Sharpton to fan the flames of racial tension).

12. But see DINESH D'SOUZA, THE END OF RACISM: PRINCIPLES FOR A MulTiRACIAL SocIETy 283-87 (1995); John Marcello, Q: Is Public Concern About Federal Police Using Racial Profiling Justified? No: Race Is Not a Part of Any Federal-Police Profile and It Never Has Been, INSIGHT, July 19, 1999, at 24, 25. Interestingly, Randall Kennedy's condemnation of the practice concedes much of the ground claimed by defenders of the practice. See Randall Kennedy, Suspect Policy, New RePublic, Sept. 13-20, 1999, at 30, 32 ("Statistics abundantly confirm that African Americans . . . commit a dramatically disproportionate share of street crime in the United States. This is a sociological fact, not a figment of the media's (or the police's) imagination."). Although Kennedy ultimately concludes that racial profiling should not be allowed, he does so out of admittedly idealistic notions. See id. at 35.

13. Racial profiling is a somewhat ambiguous term, since the practice has many forms. The most obvious definition of racial profiling is simply stopping persons solely because they are black. This practice is almost universally condemned by both courts and commentators; it is thus the least controversial aspect of the topic. See, e.g., Whren v. United States, 517 U.S. 806, 813 (1996) ("We of course agree with petitioners that the Constitution prohibits selective enforcement of the law based on considerations such as race."); United States v. Brignoni-Ponce, 422 U.S. 873, 886 (1975) ("Even if [the detaining officers] saw enough to think that the occupants were of Mexican descent, this factor alone would justify neither a reasonable belief that they were aliens, nor a reasonable belief that the car concealed other aliens who were illegally in the country."); Commonwealth v. Palmer, 751 A.2d 223, 226 (Pa. Super. Ct. 2000) ("Because the officer's identification of Appellant was predicated solely upon a vague racial description, we agree ... that articulable and reasonable grounds for the stop did not exist."). This definition is also extremely underinclusive; while there are certainly rogue officers who will pull people over based exclusively on their race, it seems that this egregious violation is most likely the excep- 
after existing for decades, profiling is now experiencing a marked increase in public attention. Part II demonstrates a need for legal change, because, under current law, courts have consistently held against plaintiffs in racial profiling cases. Finally, given the failure of the courts - at least under present law-to fashion a workable solution, Part III analyzes the costs and benefits of various proposed solutions to the problems of racial profiling. It concludes that allowing Fourteenth Amendment equal protection values to guide our understanding of what is "reasonable" under the Fourth Amendment presently offers the most practical avenue for combating profiling.

\section{BACKGROUND}

While the terms "racial profiling" and "driving while black" (DWB) seem to have a fairly recent genesis, at least in the context of police action, ${ }^{14}$ concerns over police practices disproportionately targeting or affecting minorities are older than the Republic. ${ }^{15}$ Stops for traffic offenses were used constantly for detention of black activists during the civil rights era. ${ }^{16}$ The Kerner Commission, which investigated the riots that erupted in the late 1960s, found that distrust between the police and blacks as a result of racial targeting was a pre-

tion, rather than the rule. More often than not, race is used, either consciously or unconsciously, in conjunction with other factors. Therefore, I use the definition of racial profiling suggested by Randall Kennedy: " $[R]$ acial profiling occurs whenever police routinely use race as a negative signal that, along with an accumulation of other signals, causes an officer to react with suspicion." Kennedy, supra note 12 , at 35.

14. Indeed, the term "driving while black" seems to have first been used in print by Henry Louis Gates, Jr., in 1996. See Thomas Fields-Meyer, Under Suspicion, PeOPlE WKLY., Jan. 15, 1996, at 40, 42. Similarly, no federal court case mentions "racial profiling" in the context of police action prior to December of 1998. See United States v. Leviner, 31 F. Supp. 2d 23, 33 \& n.26 (D. Mass. 1998). No reference to "racial profiling" or "race profiles" appear in law journals, at least in the criminal context, until 1993 (indeed, of the 60 documents on Westlaw which contain either term, 49 appear in 1997 or later). See Dorothy E. Roberts, Crime, Race, and Reproduction, 67 TUL. L. REV. 1945, 1951 (1993) ("Local law enforcement agencies have similarly used racial profiles to spot drug offenders on the highway."). Searches of the "ALLNEWS" database in Westlaw for either term yield the same result: of the over 3000 articles containing uses of either term, only 123 were published prior to 1996, though references to the practice go back as far as 1987. See Utah Troopers Seize Couriers in 'Cocaine Lane' Crackdown, SAN DIEGO UNION-TRIB., Oct. 8, 1987, at A32.

15. See Maclin, supra note 8, at 333-37 (1998) (detailing colonial laws subjecting AfricanAmericans to greater scrutiny than their Caucasian counterparts).

16. For example, both Malcolm X and the Rev. Martin Luther King, Jr. were the targets of race-based stops. See United States v. Harvey, 16 F.3d 109, 114 (6th Cir. 1994) (Keith, J., dissenting) (describing King's arrest for driving 30 miles per hour in a 25-mile-per-hour zone); Sheri Lynn Johnson, Race and the Decision to Detain a Suspect, 93 YALE L.J. 214, 214 (1983) (describing Malcolm X's detentions). 
cipitating cause of many of those riots. ${ }^{17}$ Yet despite the long history of this practice, it has only recently become a "hot" issue. A number of factors seem to have contributed to this, ${ }^{18}$ the most important of which have been the development of the drug courier profile, the increasing anecdotes about racial profiling that have spread as a result of the profile, and the introduction of the Traffic Stops Statistics Act of 1997.

\section{A. The Development of a "Drug Courier Profile"}

The "drug courier profile" was developed by the Drug Enforcement Agency ("DEA") to assist in the prevention of drug smuggling. ${ }^{19}$ This profile itself is not, as its name would imply, a single, coherent list of characteristics commonly found among drug dealers. Rather, it consists of a virtual laundry list of sometimes contradictory factors that agents have deemed useful in apprehending suspects. Examples of factors used by agents include, among other things, being the first off the plane, ${ }^{20}$ being the last off the plane, ${ }^{21}$ using a one-way

17. See Tracey Maclin, Terry v. Ohio's Fourth Amendment Legacy: Black Men and Police Discretion, 72 ST. JOHN's L. REV. 1271, 1295-96 (1998); see also REPORT OF THE NATIONAL ADVISORY COMMISSION ON CIVIL DISORDERS 158 (1968), quoted in Maclin, supra note 8, at 363 ("Negroes firmly believe that police brutality and harassment occur repeatedly in Negro neighborhoods. This belief is unquestionably one of the major reasons for intense Negro resentment against the police.").

18. One intriguing suggestion for the increased attention is the fact that, as a result of recent Clinton Administration initiatives, there are 100,000 new police officers on the streets today. At least one commentator has suggested that, as a result of this influx, there are more officers than ever before who have a relatively low level of training and who, as a result, are more likely to allow their pre-existing biases to influence them. See Rep. Bobby L. Rush (D-IL), Q: Should Washington Step in to Curb Police Brutality in the States? Yes: U.S. Government Involvement Is Necessary to Keep Local Police Accountable, InSIGHT, May 17, 1999, at 24. Another possible contributing factor is the upsurge in commentary following the Supreme Court's decision in Whren, where the Court explicitly held that the Fourth Amendment provided no refuge for questions of racial discrimination. See id. at 813. That decision engendered a virtual firestorm among academics. See, e.g., sources cited supra note 8; see also Kenneth Gavsie, Making the Best of "Whren": The Problems with Pretextual Traffic Stops and the Need for Restraint, 50 FLA. L. REV. 385, 391 (1998) (characterizing Whren as implicitly approving racial discrimination); David O. Markus, Whren v. United States: A Pretext to Subvert the Fourth Amendment, 14 HARV. BLACKLETTER L.J. 91, 110 (1999) (claiming that Whren undermines both the language and the purpose of the Fourth Amendment). However, neither of these suggestions warrant extended discussion at this point; the latter suggestion is discussed at length infra notes 183-202, while the former finds little discussion outside of the op-ed piece I have cited.

19. See Charles L. Becton, The Drug Courier Profile: "All Seems Infected That th' Infected Spy, as All Looks Yellow to the Jaundic'd Eye,” 65 N.C. L. REV. 417, 426 (1987).

20. See United States v. Moore, 675 F.2d 802, 803 (6th Cir. 1982).

21. See United States v. Mendenhall, 446 U.S. 544, 564 (1980). 
ticket, ${ }^{22}$ using a round-trip ticket, ${ }^{23}$ traveling alone, ${ }^{24}$ traveling with a companion, ${ }^{25}$ acting too nervous, ${ }^{26}$ and acting too calm. ${ }^{27}$ To say that profiling is an inexact science is, thus, something of an understatement. $^{28}$

Yet neither is profiling completely ineffective. Indeed, profiles result in successful seizures more frequently than would completely random stops. ${ }^{29}$ As a result of this accuracy, and because of the Supreme Court's approval of profiles in general, ${ }^{30}$ the use of profiles became increasingly prevalent throughout the 1980s and 1990s. As the use of profiling spread, however, minorities felt its impact disproportionately. ${ }^{31}$ While this fact alone is not clear proof of race discrimination, it helps to explain why, as more and more African Americans are stopped by the DEA agents on the basis of an admittedly imperfect technique, more and more allegations of racial profiling found their way into the press and the courts.

22. See United States v. Sullivan, 625 F.2d 9, 12 (4th Cir. 1980).

23. See United States v. Craemer, 555 F.2d 594, 595 (6th Cir. 1977).

24. See United States v. Smith, 574 F.2d 882, 883 (6th Cir. 1978).

25. See United States v. Fry, 622 F.2d 1218, 1219 (5th Cir. 1980).

26. See United States v. Andrews, 600 F.2d 563, 566 (6th Cir. 1979).

27. See United States v. Himmelwright, 551 F.2d 991, 992 (5th Cir. 1977). For a more complete list of factors, see David Cole, Discretion and Discrimination Reconsidered: A Response to the New Criminal Justice Scholarship, 87 GEO. L.J. 1059, 1077-78 (1999).

28. See Pedro Ruiz Gutierrez, Airport Drug Agents Say Their Job Is Not an Exact Science, ORLANDO SENTINEL, Oct. 7, 1997, at A1, available in 1997 WL 13297026.

29. Evidence used by plaintiffs in a high profile racial profiling case in Maryland indicates that over $28 \%$ of those searched were found to carry narcotics. See Wesley MacNeil Oliver, With an Evil Eye and an Unequal Hand: Pretextual Stops and Doctrinal Remedies to Racial Profiling, 74 TUL. L. REV. 1409, 1424 (2000). While this level of imprecision certainly might lead one to accept that profiling is not a justified means of law enforcement, it does-unless one is willing to argue that more than one out of every four drivers on the highway is carrying narcotics-indicate that for all its drawbacks, see notes 14-51 and accompanying text, profiling is at least somewhat effective as a means of fighting crime.

30. The Supreme Court's approval of the use of a profile that did not include race in United States v. Sokolow, 490 U.S. 1 (1989), gave further legitimacy to the use of profiling. See id. at 810 (finding that, although paying $\$ 2100$ for round-trip plane tickets, paying in cash, traveling under a false name, returning from Miami, staying in Miami for only two days, acting nervous, and not checking luggage would not by themselves justify a detention, and would, standing alone, comprise innocent behavior, taken together they constituted a reasonable, articulable suspicion for a detention).

31. For example, an airport police officer in Memphis stated that $75 \%$ of those followed and questioned in his airport are African-American. See Cole, supra note 27, at 1079. One author notes that $95 \%$ of drug courier profile cases from 1990 to 1995 involved minority defendants. See id. (citing David Cole, No Equal Justice: RACE AND Class IN THE AMERICAN CRIMINAL JUSTICE SYSTEM 50 (1999)). 


\section{B. Increasing Anecdotes}

As noted above, the news media began to report on racial profiling by the police long before the courts or the academy picked up on the practice. ${ }^{32}$ These accounts have brought a number of striking instances of alleged racial profiling to the public's attention.

1. Volusia County, Florida. In the late 1980s, Sheriff Bob Vogel and his deputies began applying a drug profile to the stretch of I-95 that ran through Volusia County, Florida. ${ }^{33}$ Although Vogel kept no statistics on the number of people pulled over, a team of reporters from the Orlando Sentinel obtained several hours of videotaped footage from officers, detailing over 1100 stops. $^{34}$ The Pulitzer Prizewinning reporting that followed revealed that $70 \%$ of those pulled over were black or Hispanic, even though minority motorists constituted only $5 \%$ of drivers along this particular stretch of highway. ${ }^{35}$ While the Eleventh Circuit found this evidence insufficient to sustain a lawsuit, ${ }^{36}$ the footage revealed some particularly damning stories to the public. For example, one black man stated that he was pulled over seven times; another claimed to have been stopped twice within minutes. ${ }^{37}$ In one of the most famous scenes, taken from an officer's tape that had been turned over to the newspaper, Sergeant Dale Anderson approached a white motorist who had been pulled over for speeding. Anderson asked the man how he was doing. The driver replied, "Not very good," to which Anderson countered,

32. See supra note 14 .

33. See Harris, supra note 8, at 561 (describing Vogel's Selective Enforcement Team drug interdiction effort); Gary Webb, Driving While Black, EsQUIRE, Apr. 1999, at 122 (describing Vogel's profile as including air fresheners (which can thwart drug dogs), fast-food wrappers, maps with "drug source" cities circled, tools on the floor (for accessing hidden compartments), a single key in the ignition (since most people travel with keys on keyrings), and a failure to bring enough luggage for a long trip). Vogel is largely credited with creating the technique of pretextual stops: identifying a suspicious-looking individual, following her, and then waiting for her to commit a minor traffic violation. See Webb, supra, at 123.

34. See Harris, supra note 8, at 562 (describing the disproportionate number of minorities detained, as revealed by the videotapes); Webb, supra note 33, at 127 (noting that 148 hours of videotape were given to the newspaper).

35. See Harris, supra note 8, at 561-62. These statistics are high, even compared to other Florida rates. Another Sentinel survey revealed that $50 \%$ of detainees were black, even though only $16 \%$ of the motorists were African-American. See Akilah Monifa, Don't Drive While Black, SPEAKIN' Out NeWs, Aug. 11, 1998, at 7, available in 1998 WL 29221790; Rose, supra note 11.

36. See infra notes 127-28 and accompanying text.

37. See Harris, supra note 8 , at 562 . 
replied, "Not very good," to which Anderson countered, "Could be worse. Could be black." ${ }^{38}$

2. Robert Wilkins and the Maryland Studies. On May 8, 1992, Robert Wilkins, an African-American Harvard Law School graduate and public defender for the District of Columbia, was riding in a car that was pulled over on I-68 near Cumberland, Maryland. ${ }^{39}$ The detaining officer requested permission to search the car. Wilkins's cousin, who was driving, refused, and Wilkins cited case law to illustrate the illegality of the search. The officer ignored both the refusal and the warning, and ordered Wilkins and his family to stand in the rain while a drug dog sniffed their car. ${ }^{40}$ When the search yielded nothing, the officer simply issued Wilkins's cousin a traffic ticket and released them. ${ }^{41}$

Wilkins contacted the American Civil Liberties Union ("ACLU") and filed suit. During discovery, the ACLU found a smoking gun of the caliber of which most attorneys only dream: the Maryland State Police had, only a week earlier, published a memo asking police officers to be on the lookout for drug couriers, who would be "predominantly black males and black females." ${ }^{42}$ As a part of the resulting settlement agreement, the Maryland police were required to keep statistics on the number of African Americans stopped and searched. ${ }^{43}$ The results were not encouraging for the state. Seventy-three percent of those stopped were African Americans, even though African Americans constitute a much smaller fraction of drivers on the highway. ${ }^{44}$ Although a closer examination of the statistics (usually ignored by commentators on the subject) seems to imply that some factor other than race explains the discrepancy, ${ }^{45}$ a lawsuit has been refiled by Wilkins.

38. Webb, supra note 33, at 127.

39. See Davis, supra note 8, at 438-39; "Driving While Black" Is Not a Crime ... So Why Are Incidents Like These Occurring Across the Country? (last visited Aug. 19, 2000), http://www.aclu.org/profiling/background/roster.html (on file with the Duke Law Journal).

40. See Davis, supra note 8 , at $439-40$.

41. See id. at 440.

42. COLE, supra note 31, at 36 .

43. See Davis, supra note 8 , at 440 .

44. See id.

45. A number of factors are typically underreported in descriptions of this statistical discrepancy. For example, $37 \%$ of the officers assigned to this particular stretch of highway were black, as was the commanding officer. See David Crump, Evidence, Race, Intent and Evil: The Paradox of Purposelessness in the Constitutional Racial Discrimination Cases, 27 HOFSTRA L. REV. 285, 322 (1998). Thus, the popular conception of racial profiling as a black/white issue that 
these statistics are meant to buttress badly oversimplifies reality. In addition, the data were taken solely from people pulled over for speeding, which may not be a good proxy for people pulled over for other traffic violations. See id. at 325.

Moreover, John Lamberth, the statistician who analyzed the data for the plaintiffs, "controlled" for variance in rate of speed in the following manner: He set his cruise control at five miles over the speed limit, and observed the race of each driver who they passed or who passed them. See David A. Harris, The Stories, the Statistics, and the Law: Why "Driving While Black” Matters, 84 MinN. L. REV. 265, 278 (1999). From this, Lamberth concluded that blacks were speeding at roughly the same rate as whites. See id. However, this is not an effective control; it seems (at least from personal experience) that the vast majority of drivers on the New Jersey Turnpike go more than five miles per hour over the speed limit. Given the impracticality of stopping almost every driver on the highway, officers seem likely to wait for more egregious offenders to ticket. If Lamberth had incrementally raised his rate of speed and proved that African Americans speed at the same rates as whites at 10,15,20, and 30 miles per hour over the speed limit, his argument would be much more credible. (This is only to suggest that Lamberth's report is not nearly as conclusive as has been suggested, not that I believe African-American drivers $d o$ in fact speed more frequently than whites.)

Most importantly, though, Lamberth reported that, of the cars searched, contraband was found in exactly the same proportion for blacks as for whites. See John Lamberth, Driving While Black: A Statistician Proves that Prejudice Still Rules the Road, WASH. POST, Aug. 16, 1998, at C1. If officers were to use an extraneous factor such as race as part of their proxy for criminality, then they presumably would have lower success rates with the group subjected to that extraneous proxy.

For example, assume I search for murder suspects and have a fairly good profile including prior history, living alone, etc. Now, assume that I add an extraneous factor to the mix. Say, for example, I look for people with red shoes as well. Since I am now considering an irrelevant factor, my success rate among people brought in under that factor should be lower than for people who were not stopped because of their shoe color. Similarly, if "blackness" is used as a proxy for criminal behavior, and it is not a good indicator of criminal behavior, then the blacks subjected to stops on the basis of that factor should have contraband seized at a lower rate than whites who are not subjected to that.

Of course, if police also pay more attention to more accurate proxies for drug trafficking (whatever those may be) when detaining blacks, this could conceivably negate the effect of using an inaccurate proxy such as race to initiate an encounter. It strikes me as highly unlikely, however, that the "cancellation effect" would be exact enough to completely counteract the effect of the extraneous proxy.

This should not be interpreted as arguing that race is a good proxy for criminality or that these statistics justify profiling. If race were used and it was a good proxy for drug running, then we would expect to see higher rates of seizures for African-American motorists, which we do not see. Thus, unless police pay more attention to accurate profile characteristics when blacks are stopped — a very real possibility—it appears that an extraneous factor accounts for the discrepancy.

What this factor would be is difficult to speculate upon. One possibility is that the same factors that contribute to the higher crime rate among African-Americans for violent offenses, see Kennedy, supra note 12 , at 32 , contribute to a higher rate of traffic offenses as well. See Crump, supra, at 323. This argument, however, may rely too much upon negative stereotypes of the black community. A more refined version of this argument contends that the logical nexus between environmental factors (such as poverty or broken homes) and violent crime seems much stronger than that between environmental factors and traffic offenses. One possible way that this could play out, however, is if, as a result of diminished economic capacity, AfricanAmericans were less able than their Caucasian counterparts to repair broken taillights, have 
3. Other High-Profile Anecdotes. Recent years have seen various other anecdotes regarding the incidence of racial profiling on the highways. For example, New Jersey Governor Christine Todd Whitman has admitted very frankly that racial profiling occurs in New Jersey. ${ }^{46}$ A New Jersey state trooper validated this admission by filing suit, claiming that he was required to implement a racial profile. ${ }^{47}$ In Reynoldsburg, Ohio, an African American secured a settlement after he was arrested by a group of officers who called themselves the Special Nigger Arrest Team. ${ }^{48}$

Probably of the most immediate impact, however, are the many cases involving "celebrity stops." Marcus Allen, LeVar Burton, Johnnie Cochran, Christopher Darden, Miles Davis, Michael Eric Dyson, Al Joyner (twice within twenty minutes), Wynton Marsalis, Edwin Moses, Will Smith, and Wesley Snipes have all complained of arbitrary stops on the basis of their skin color. ${ }^{49}$ And, in a recent survey of the Congressional Black Caucus, 18 of the 39 members claimed "they or someone in their immediate family had been stopped for no reason other than the color of their skin." ${ }^{, 50}$ In the words of Representative Elijah Cummings (D-MD), "This (racial profiling) is something that's been plaguing me ever since I started driving. ... If you're a black man, even if you're a member of Congress, a cop is going to pull you over." ${ }^{, 51}$

speedometers adjusted, fix cracked windshields, etc. See id. at 323. Whatever the reason for the discrepancy, these particular data imply that race is not that reason in New Jersey or Maryland, or, at the very least, that a properly controlled study has not been conducted.

46. See Taylor, supra note 11, at 1084 .

47. See New Jersey State Trooper's Lawsuit Alleges Racial Traffic Stops, LiAB. WeEK, Feb. 8, 1999, available in 1999 WL 13960397.

48. See Davis, supra note 8, at 432. Similar stories have been heard throughout the nation. In Boca Raton, Florida, a man filed a civil rights complaint after police demanded that he show identification when he crossed a parking lot alone near the site of a recent robbery. See Boca Raton Cops Deny Racial Profiling, FlA. TodAy, July 29, 1999, at 5B, available in 1999 WL 18273725. And in 1997, PrimeTime Live lost a lawsuit for airing an exposé allegedly unveiling racial profiling of a specially videotaped "test" car. In the police officers' defense, they maintain that a passenger in the test car kept his hands in his lap after being asked three times to move them, and refused to step out of the car. In addition, local police did, in fact, question the white members of the crew of the parked ABC van, though this was not reported. See Timothy Noah, Sorting Out What the Hidden Camera Saw: ABC's PrimeTime Live Gets Sued Again, U.S. News \& WORLD REP., Dec. 22, 1997, at 64, 66.

49. See Russell, supra note 8, at 720 n.15. The son of Detroit Mayor Dennis Archer filed a complaint after being stopped because he allegedly looked like an armed robbery suspect. See Son of Detroit Mayor Files Complaint After Being Stopped by Police, JET, Aug. 30, 1999, at 54.

50. Minority Lawmakers Speak Out, House RACE HOTLINE, May 14, 1999, available in 1999 WL 27578917 (detailing members of the Congressional Black Caucus who claim to have been victimized by racial profiling) (quotation marks omitted).

51. Id. 


\section{The Traffic Stops Act of 1997 and the ACLU Campaign to "Arrest the Racism"}

In response to these concerns, Representative John Conyers (DMI) introduced The Traffic Stops Statistics Act of $1997 . .^{52}$ This Act would have, in part, required the Justice Department to study the rates at which African-American motorists are pulled over by police officers. ${ }^{53}$ Much to everyone's surprise, the bill passed the House. ${ }^{54} \mathrm{Al}-$ though the Senate did not act upon the bill, Representative Conyers reintroduced the Act in the 106th Congress. ${ }^{55}$

Although it did not, and probably never will, become law, partly due to strong opposition by police officers, the passage of the Conyers Bill by the House brought a huge volume of media attention to the issue of racial profiling. ${ }^{56}$ In response to this heightened focus, the ACLU launched a nationwide campaign to end the use of racial profiling by police officers. ${ }^{57}$ As part of this campaign, the ACLU called upon Attorney General Janet Reno to investigate the use of racial profiling, placed ads in Emerge magazine, established a free "DWB Hotline," and placed a site on the Internet. ${ }^{58}$

After reading an ad in Emerge magazine, Rossano V. Gerald contacted the ACLU regarding his detention by Oklahoma state troopers. ${ }^{59}$ Thus began the first suit of the ACLU campaign. ${ }^{60}$ Part II

52. Id.; see also H.R. 118, 105th Cong. (1997) (providing for the collection of data during routine traffic stops).

53. For details of the Conyers bill, see infra notes $238-42$ and accompanying text. For now, I focus upon how it advanced the public consciousness of racial profiling. See Conyers Pushes Bill to Gather Info on 'Driving While Black' Traffic Stops, JET, May 3, 1999, at 4.

54. See id.

55. See H.R. 1443, 106th Cong. (1999) (providing for the collection of data during routine traffic stops).

56. See, e.g., Erin Texeira, Bill Would Track Bias in Traffic Stops, LAS Vegas ReV. J., Aug. 17, 1998, at A1 (detailing the bill and the opposition engendered by police).

57. See Russell, supra note 8, at 719-20; David Harris, Driving While Black: Racial Profiling on Our Nation's Highways (last visited Nov. 11, 1999), http://www.aclu.org/profiling/report/ index.html (on file with the Duke Law Journal); Arrest the Racism (last visited Nov. 11, 1999), http://www.aclu.org/profiling/background/index.html (on file with the Duke Law Journal).

58. See ACLU Launches Special Web Collection, supra note 7. The ACLU was allegedly flooded with responses to these ads. See Tammerlin Drummon, It's Not Just in New Jersey: Cops Across the U.S. Often Search People Just Because of Their Race, a Study Says, TIME, June 14, 1999 , at 61.

59. See ACLU Launches Special Web Collection, supra note 7.

60. See Johnson, supra note 3, at 3A. Another case involving a detention in an airport has been filed. See In Case of "Flying While Black," U.S. Customs Service Subjected Woman to Harrowing Search, ACLU Charges (last visited Nov. 21, 1999), http://www.aclu.org/news/1999/ n111799a.html (on file with the Duke Law Journal). 
of this Note examines the problems that Gerald and other plaintiffs have encountered.

\section{RECENT CASES ILLUSTRATE THE DifFICULTY THE STATUS QUO PRESENTS TO RACIAL PROFILING CLAIMS}

Several structural barriers currently prevent the pursuit of racialprofiling claims in the courts. At the outset, a plaintiff is unlikely to be able to establish standing to seek injunctive relief-the most obvious remedy for a police practice-and will have great difficulty proving a violation of the Equal Protection Clause of the Fourteenth Amendment. However, and perhaps most surprisingly, even if a plaintiff successfully demonstrates standing to sue and survives summary judgment on the merits of her Fourteenth Amendment claim, her suit will likely be dismissed, on the ground that even explicit racial profiling is a constitutionally permissible technique for law enforcement officers. This part of the Note explores each of these litigation hurdles in order.

\section{A. Standing}

Cases challenging racial profiling face difficulty from the outset. Article III of the United States Constitution grants the federal courts jurisdiction over only "cases" and "controversies." Court has interpreted this as prohibiting courts from rendering opinions that simply advise the President or Congress of the propriety of legislation. ${ }^{62}$ Specifically, a plaintiff must first suffer a concrete and particularized "injury in fact," which must be "actual or imminent, not 'conjectural' or 'hypothetical.", ${ }^{63}$ Additionally, courts have re-

61. U.S. CONST. art. III, § 2.

62. See Muskrat v. United States, 219 U.S. 346, 361 (1911) ("That judicial power, as we have seen, is the right to determine actual controversies arising between adverse litigants, duly instituted in courts of proper jurisdiction."); Letter from Chief Justice Jay and Associate Justices to President Washington (Aug. 8, 1793), in 3 CORRESPONDENCE AND PUBLIC PAPERS OF JOHN JAY 489 (Henry P. Johnston ed., 1891).

63. Lujan v. Defenders of Wildlife, 504 U.S. 555, 560 (1992) (quoting Whitmore v. Arkansas, 495 U.S. 149, 155 (1990) (quoting Los Angeles v. Lyons, 461 U.S. 95, 102 (1983))); see also Warth v. Seldin, 422 U.S. 490, 508 (1975) ("[A] Plaintiff must allege specific, concrete facts demonstrating that the challenged practices harm him ...."). 
quired that the injury be traceable to some action of the defendant. ${ }^{64}$ Finally, the injury must be one that courts are able to redress. ${ }^{65}$

These requirements historically have created problems for plaintiffs who seek injunctive relief against police practices. The seminal Supreme Court decision controlling such facts is City of Los Angeles v. Lyons. ${ }^{66}$ There, Adolph Lyons filed a complaint seeking injunctive and declaratory relief against several police officers for an alleged chokehold suffered at the hands of the Los Angeles Police Department ("LAPD"). ${ }^{67}$ The Supreme Court held that the threat of Lyons suffering another injury was far too speculative to satisfy the standing requirement. As the Court put it:
Absent a sufficient likelihood that he will again be wronged in a similar way, Lyons is no more entitled to an injunction than any other citizen of Los Angeles; and a federal court may not entertain a claim by any or all citizens who no more than assert that certain practices of law enforcement officers are unconstitutional. ${ }^{68}$

Thus, previous encounters with police do not satisfy the standing requirement for an Article III case or controversy "if unaccompanied by any continuing, present adverse effects." ${ }^{69}$

Courts have used this requirement to dismiss the several cases that have attempted to secure injunctive relief from racial profiling, including Gerald's. Although the detailed facts of Gerald v. Department of Public Safety ${ }^{70}$ are fascinating, for the purposes of this narrative, it is enough to state that Gerald was detained by Oklahoma Troopers for allegedly failing to signal a lane change and evidenced behavior that the detaining troopers claimed rose to a level of reasonable, articulable suspicion that justified further detention. After a drug dog allegedly detected drugs near the wheel well of Gerald's car, Gerald was handcuffed, and he and his son were placed in an un-airconditioned squad car. ${ }^{71}$ A two-hour search then ensued. The detain-

64. See Simon v. Eastern Ky. Welfare Rights Org., 426 U.S. 26, 41-42 (1976) (“Art. III still requires that a federal court act only to redress an injury that fairly can be traced to the challenged action of the defendant.").

65. See Lujan, 504 U.S. at 562.

66. 461 U.S. 95 (1983).

67. See id. at 97.

68. Id. at 111 .

69. Id. at 102 (quoting O'Shea v. Littleton, 414 U.S. 488, 495-96 (1974)).

70. No. CIV 99-676-R (W.D. Okla. May 18, 1999).

71. The facts in detail are as follows: Sergeant First Class (SFC) Rossano V. Gerald and his son, Gregory, were traveling westbound on Interstate 40 in a red sports car to visit their family. 
ing officer, Trooper Perry, removed "parts of the headliner, floorboards, carpet, and other areas" of the car. ${ }^{72}$ However, no drugs were found..$^{73}$ The officers repacked Gerald's car and let him go with a warning ticket. ${ }^{74}$

See First Amended Complaint and Jury Demand at 6-7, Gerald v. Department of Pub. Safety (W.D. Okla. May 18, 1999) (No. CIV 99-676-R). Soon after crossing the Oklahoma border, Gerald allegedly was stopped by a police officer for the City of Roland, and was issued a warning. See id. at 7. Shortly thereafter, two Oklahoma State Troopers pulled onto the interstate and stopped him. See id. at 8.

Oklahoma Troopers Perry and Knoke approached Gerald, ordered him to get out of the car, and placed him in the front seat of Trooper Perry's car. There, he was informed that he was being pulled over for failing to signal a lane change, though Gerald maintains that he did in fact signal the change. See id. at 8-9. Gregory was asked to step out of the car and was placed in the back seat of Trooper Perry's car. See id. at 9. Trooper Perry then asked Gerald why he was acting nervously. See id.; Johnson, supra note 3. Gerald, apparently erroneously believing that his initial stop was by another Oklahoma Highway Patrolman, replied that he was upset because he had recently been stopped by another trooper. See First Amended Complaint at 9, Gerald (No. CIV 99-676-R). Trooper Perry called and found that Gerald had not in fact been detained by a state trooper (the highway patrol records do not record local law enforcement stops, such as that conducted by the City of Roland's officer). Convinced that Gerald was lying, Perry asked permission to search Gerald's car. See id. This permission was refused. See id.

Trooper Perry asked Gerald whether he was carrying any weapons, contraband, or illegal material; Gerald answered in the negative. See id. at 10. Gerald then counted his money, which was noted by Trooper Perry. See id.

Trooper Perry called on Trooper Knoke to run a drug dog by the car. Gerald insisted on being allowed to watch the search, and was allowed to do so, though he was told to stand away from the car. See id. at 11. Trooper Knoke stated that the dog had alerted near the wheel well of the car, though Gerald maintains that the dog failed to make any noises or indications of suspicious behavior. See id. at 11 . Trooper Perry also allegedly turned off the patrol car's air conditioning unit at this point. See id. at 12. Gerald and his son were ordered back into Trooper Perry's patrol car. See id. at 11-12.

Troopers Perry and Knoke proceeded to search Gerald's car. After using a drill to remove part of the front passenger floorboard, Trooper Perry announced that they had found a secret compartment with drug residue. See id. At some point, the hood of Trooper Perry's car was raised, which had the effect of obscuring the view of the patrol car's dashboard camera and Gerald and Gregory's views of the search. See id. at 14. Troopers Perry and Knoke maintain that this action was taken to help air condition the car. (In fact, opening the hood of a car can help an air conditioning unit cool a car if it is not operating properly.) Gerald was placed in handcuffs. See id. at 12. Gregory was separated from his father and placed in Trooper Colbert's car. See Johnson, supra note 3 . There, he was allegedly interrogated and frightened by a barking drug dog. See id.

72. First Amended Complaint at 13, Gerald (No. CIV 99-676-R).

73. See id.

74. See id. at 15 . Here, there is another dispute. Gerald maintains that Troopers Perry and Knoke offered a sarcastic remark, and sloppily repacked the car. Troopers Perry and Knoke, on the other hand, maintain that Gerald had relaxed tremendously after the conclusion of the search, that as a result they had begun joking with him, and that they had, in fact, repacked his car to the best of their ability. See id. 
Gerald brought suit under section 1983 of Title 42 of the United States Code ${ }^{75}$ basing his claim upon violations of the Equal Protection Clause of the Fourteenth Amendment, ${ }^{76}$ the "unreasonable search and seizure" clause of the Fourth Amendment, ${ }^{77}$ and the Fourteenth Amendment "right to travel.," Gerald named a multitude of defendants, ${ }^{79}$ and sought equitable relief $^{80}$ as well as punitive and compensatory damages. ${ }^{81}$

Despite the unusual amount of evidence offered before discovery had even taken place, ${ }^{82}$ most of Gerald's claims were dismissed. The

75. 42 U.S.C. $\$ 1983$ (1994). Section 1983 is a Reconstruction-era civil rights statute that provides:

Every person who, under color of any statute ... of any State or Territory ... subjects, or causes to be subjected, any citizen of the United States or other person within the jurisdiction thereof to the deprivation of any rights, privileges, or immunities secured by the Constitution and laws, shall be liable to the party injured in an action at law, suit in equity, or other proper proceeding for redress. Id.

76. U.S. CONST. amend. XIV, $§ 1$ ("No State shall . . deny to any person within its jurisdiction the equal protection of the laws.").

77. U.S. CONST. amend. IV ("The right of the people to be secure in their persons, houses, papers, and effects, against unreasonable searches and seizures, shall not be violated ....").

78. There is substantial disagreement as to the exact genesis of this right. See, e.g., Kent v. Dulles, 357 U.S. 116, 125 (1958) (placing the right to travel in the Fifth Amendment's Due Process Clause); Edwards v. California, 314 U.S. 160, 172 (1941) (finding the right to travel to be grounded in the Commerce Clause); $i d$. at 178 (Douglas, J., concurring) (asserting that the right is located in the Fourteenth Amendment's Privileges and Immunities Clause); id. at 182 (Jackson, J., concurring) (same); The Passenger Cases, 48 U.S. 283, 408-09 (7 How.) (1849) (finding the right to be grounded in the Commerce Clause); Corfield v. Coryell, 6 F. Cas. 546 (C.C.E.D. Pa. 1823) (No. 3,230) (grounding the right in the Privileges and Immunities Clause of Article IV, $\S 2$ ). The Court's most recent pronouncement on the right to travel, Saenz v. Roe, 526 U.S. 489 (1999), grounds the right in the Privileges and Immunities Clause of the Fourteenth Amendment. See id. at 501-08.

79. Named defendants included Bob Ricks (the Commissioner of Public Safety), Governor Frank Keating, Gary Adams (Chief of the Highway Patrol Division of the Oklahoma Department of Public Safety), and Oklahoma State Troopers Branson Perry, Russell Knoke, Bob Colbert, and Jim McBride. See First Amended Complaint at 4-6, Gerald (No. CIV 99-676-R). Gerald also brought suit under Title VI of the Civil Rights Act of 1964, 42 U.S.C. § 2000d (1994). See id. at 2. This provision provides that "[n]o person in the United States shall, on the ground of race ... be ... subjected to discrimination under any program . . . receiving Federal financial assistance." 42 U.S.C. $\$ 2000$ d. In the interests of space, I do not discuss this aspect of the suit, even though it was one of the few claims not to be dismissed. See Gerald v. Department of Pub. Safety, No. CIV 99-676-R, slip op. at 15 (W.D. Okla. Dec. 21, 1999) (order granting motion to dismiss in part and denying motion to dismiss in part regarding the vicarious defendants).

80. Gerald requested declaratory judgments that the Oklahoma Highway Patrol had engaged in unconstitutional police activity and an injunction against further racial profiling on the highway. See First Amended Complaint at 27-28, Gerald (No. CIV 99-676-R).

81. See First Amended Complaint at 28, Gerald (No. CIV 99-676-R).

82. Gerald offered, among other things, an affidavit from Richard Allen, President of the Oklahoma National Association for the Advancement of Colored People (NAACP) contending that complaints of racial profiling arose at nearly every meeting of the Chapter. See id. Ex. B; 
U.S. District Court for the Western District of Oklahoma, Chief Judge Russell, held that Gerald lacked standing to pursue an injunction or a declaratory judgment, because Gerald could not prove a "real and immediate" injury or threat of injury. ${ }^{83}$ All counts against the non-trooper defendants were dismissed, except for the Title VI claim against the Department of Motor Vehicles.

The result of this case illustrates that, for a plaintiff such as Gerald, who rarely travels across an area and is only occasionally stopped (and is even less frequently subjected to a racially motivated stop), the chances of securing injunctive relief are virtually non-existent. Although Gerald alleged that he would continue to use the highways of Oklahoma periodically to visit family residing in the state, the court rejected his claim, noting that "[a]n expectation that an individual will travel on an interstate highway in [Oklahoma] or confidence that this event will occur represent conjectural rather than concrete intentions." ${ }^{, 5}$

Several other racial profiling cases brought by individual plaintiffs have been rejected for lack of standing. In Chavez v. Illinois State Police, ${ }^{86}$ a paid investigator was pulled over by a police officer, allegedly on the basis of his race. ${ }^{87}$ The U.S. District Court for the North-

see also id. Ex. E (Affidavit of Thomas E. Hawkins) (relating that similar experiences had occurred to Hawkins on May 3, 1998). Gerald also introduced some evidence supporting his claim of a custom of racial discrimination in the Oklahoma Highway Patrol. See id. Ex. C-D. These stories included a case that had garnered some media attention when George Singleton, a black Rastafarian, was stopped and put on trial for allegedly driving under the influence of rosemary and mullein. See Omer Gillham, Rastafarian Awaits Ruling on Dismissal of Herb Case, TULSA WORLD, Oct. 2, 1998, at 1, available at 1998 WL 11154288. Gerald also unearthed previous allegations of misconduct by Trooper Perry. See First Amended Complaint at Ex. G, Gerald (No. 99-676-R) (reprinting 1995 Tulsa World story of Trooper Perry stopping Capt. Janella Spurlock, approaching her car with a gun drawn, and forcing her to the ground with his gun drawn, leaving an imprint from the barrel of his gun in her back). As an aside, reminiscent of a scene from $\mathrm{Na}$ tional Lampoon's Vacation, investigative reporting following the filing of Gerald's suit included a tale of a police officer who accidentally took off with his drug-sniffing dog tied to his car. See Michael Overall, ACLU Files Racism Lawsuit, TULSA WORLD, May 19, 1999, available in 1999 WL 5400845. The dog survived.

83. See Gerald, No. CIV 99-676-R, slip op. at 16.

84. See id. at 22.

85. Id. at 16 (quoting Chavez v. Illinois State Police, No. 94 C 5307, 1999 WL 592187, at *15 (N.D. Ill. Aug. 2, 1999)).

86. 27 F. Supp. 2d 1053 (N.D. Ill. 1998), reconsideration denied, No. 94 C 5307, 2000 WL 91918 (N.D. Ill. Jan. 19, 2000).

87. The facts of Chavez are interesting enough to warrant further explication. The case arose from the stop of a white defendant, George Koustakis. See id. at 1061. Koustakis was stopped for speeding (though he denied that he was speeding), searched, and arrested when 250 pounds of marijuana were discovered in his car. See id. at 1061-62. In an attempt to free her client, Koustakis's lawyer attempted to prove that the Illinois Highway Patrol regularly engaged in 
ern District of Illinois rejected the last of the three named plaintiffs' several attempts to plead a sufficient case to begin discovery. ${ }^{88}$ The court noted that Chavez himself "was stopped once, over six years ago," and that his "inchoate intention" to return to the state "does not establish that Chavez will even be on an Illinois highway at a definite point in the future, let alone that he will experience the kind of real and immediate injury contemplated by Lyons." $"$

Regarding Chavez's second named plaintiff, Gregory Lee, the court began by noting that Lee's alleged last stop had occurred almost seven years prior. ${ }^{90}$ During that time, he claimed to have traveled the highways in Illinois sixty times per year, which, as the court sarcastically noted, put him "a step ahead of Chavez." ${ }^{\text {"11 }}$ Notwithstanding this, the court held that Lee's frequent trips did not mean that he was in danger of being injured in the future ${ }^{92}$ and denied Lee standing to pursue equitable relief. ${ }^{93}$

The result in the case arising from Sheriff Vogel's efforts in Volusia County ${ }^{94}$ is similar. In Washington v. Vogel, ${ }^{95}$ the court noted that the plaintiff, Selena Washington, had not been pulled over in almost four years, ${ }^{96}$ much longer than the five months' passage that the Supreme Court had found significant in Lyons. ${ }^{97}$ The court also noted

pretextual stops. Her plan was simple: hire a minority driver, follow him around until he is pulled over, and see if he had, in fact, committed any traffic violations. See id. at 1062.

Koustakis's attorney hired Peso Chavez, who emulated Koustakis's circumstances (driving a rented red sports car with California license plates, with open maps, fast food wrappers, a cellular phone, and a gym bag in plain view). See id. After a day of driving without being pulled over, Chavez was finally followed for half an hour by Trooper Larry Thomas. After allegedly failing to signal a lane change (which Koustakis's attorney, who was following at the time, denied), Chavez was pulled over, and his car was searched. See id. This suit ensued, which claimed that his initial stop was motivated solely by consideration of his race. See id. at 1064 .

88. See Chavez, 1999 WL 592187, at *22.

89. Id. at *14-*15 (quotation marks omitted).

90. See id. at *15.

91. Id.

92. As the court put it, to do so, Lee would need to allege that he would have an encounter with the Illinois State Police, and also that "all Illinois State Police officers always discriminate against minority citizens with whom they have an encounter or that the State ordered or authorized its police officers to act in such a manner." $I d$. at *16.

93. As to the third defendant, Joseph Gomez, the court noted that he was presently incarcerated on drug charges and that because "the record establishes that Gomez will not be driving anywhere on his own volition for at least seven years, the court finds that he cannot satisfy $L y$ ons' imminent harm requirement." $I d$. at *19.

94. See supra notes 33-38 and accompanying text.

95. 156 F.R.D. 676 (M.D. Fla. 1994).

96. See id. at 680.

97. See id. (citing City of Los Angeles v. Lyons, 461 U.S. 95, 108 (1983)). 
that Washington lived in South Carolina and had only traveled the stretch of highway through Volusia County a couple of times since her initial encounter. ${ }^{98}$ Thus, the court denied Washington's claim for injunctive relief for want of Article III jurisdiction. ${ }^{99}$

Taken together, these cases illustrate at least three factors courts examine to determine whether a plaintiff has established standing to sue. First, courts examining racial profiling claims will not grant standing when substantial time has lapsed between the injury and the litigation, yet no repetition of the injury has occurred. This lack of repetition is mentioned by the Lyons, Chavez, and Washington courts; though it never seems dispositive, it is a factor that is consistently addressed.

Second, courts will not allow individual plaintiffs to pursue equitable relief in racial profiling cases. This ties in with the above analysis; an individual is much less likely to suffer a similar deprivation in the future than a certified class, or even a suit with multiple plaintiffs. The Gerald court made this explicit when it attempted to distinguish Gerald's case from various cases cited by the plaintiffs: "The majority of [cases cited by plaintiffs] involved more than one plaintiff alleging sufficient threat of imminent future harm.,"100

Finally, courts are not sympathetic to plaintiffs who seek injunctive relief for injuries derived from illegal behavior. It is far more conjectural, courts hold, to assert that one will be subjected to a stop in the future when the "triggering incident" is a specific action such as speeding, than it is to assert that one will be stopped for something as commonplace as simply driving or walking. ${ }^{101}$

Consideration of cases where standing to pursue equitable relief has been granted confirms this analysis. For example, in National Congress for Puerto Rican Rights v. City of New York, ${ }^{102}$ a civil rights organization and six black and Latino men brought action against the City of New York, Mayor Rudy Giuliani, Police Commissioner How-

98. See Washington, 156 F.R.D. at 680-81.

99. See id. at 681.

100. Gerald v. Department of Pub. Safety, No. CIV 99-676-R, slip op. at 9 (W.D. Okla. Dec. 21,1999 ) (granting motion to dismiss in part and denying motion to dismiss in part regarding the vicarious defendants).

101. See, e.g., Lyons, 461 U.S. at 108 ("[I]t is surely no more than speculation to assert . . that Lyons himself ... will be arrested in the future ....").

102. 191 F.R.D. 52 (S.D.N.Y. 1999). 
ard Safir, and 500 unnamed police officers. ${ }^{103}$ Each plaintiff alleged that police officers had stopped and frisked them without reasonable suspicion. Unlike Gerald, however, the National Congress plaintiffs also alleged that they had been stopped more than once. ${ }^{104}$

The U.S. District Court for the Southern District of New York held that Lyons was distinguishable..$^{105}$ In doing so, the National Congress court placed considerable importance on the fact that the plaintiffs had alleged that the victimization was an ongoing process, rather than an isolated past incident. ${ }^{106}$ It also noted that "there is the difference in the number of alleged constitutional violations resulting from the challenged policies" that created the inference of "a pervasive pattern of unconstitutional stops and frisks," affecting "tens of thousands of New York City residents."107 Thus, the court found that the first and second factors identified above were absent. It also bears mentioning that the people stopped were innocent pedestrians who fit a profile, not drivers who had allegedly committed traffic violationsalthough the court did not explicitly consider this, the third factor above was therefore not present.

The case flowing from Wilkins's detention, ${ }^{108}$ Maryland State Conference of NAACP Branches v. Department of State Police, ${ }^{109}$ also shows that, when the above factors are absent, courts are willing to let claims for injunctive relief proceed. In State Conference, the state branch of the NAACP was party to the suit. The class of plaintiffs was, therefore, large enough to increase dramatically the likelihood that future injury would occur, demonstrating the absence of the first and second factors. ${ }^{110}$ Finally, the court observed the absence of the third factor, distinguishing Lyons: "Any 'illegal' action on their part associated with the future stop need be no more than a minor, perhaps unintentional, traffic infraction; indeed, according to their alle-

103. See National Congress for Puerto Rican Rights v. City of New York, 75 F. Supp. 2d 154, 158 (1999). This case involved the famous Street Crime Unit of the New York Police Department.

104. See id. at 159 \& n.3.

105. See id. at 161.

106. See id.

107. Id.

108. See supra notes 39-45 and accompanying text.

109. 72 F. Supp. 2d 560, 564-66 (D. Md. 1999).

110. See id. at 565. The court found this especially convincing in light of the statistical evidence purporting to show that the Maryland Highway Patrol engaged in a pattern of discriminatory stops. See id. 
gations, they may be stopped even if no traffic violation has been committed." ${ }^{111}$

Thus, when substantial time has not elapsed between the injury and litigation (or where the passage of time shows repeated injuries to plaintiffs), when a large number of plaintiffs are present, ${ }^{112}$ and when these plaintiffs do not have to commit infractions to run afoul of the law, ${ }^{113}$ courts are receptive to claims for equitable relief. While this does little for the individual plaintiff pulled over in a state where injunctive relief has not yet been granted, it does show that not all suits for injunctive relief will be dismissed at the gates. Also, none of what precedes bars suits for damages. However, it does show that the most direct legal way of ending profiling-equitable relief-is largely foreclosed by fairly sensible doctrines emanating from Article III. Moreover, once this initial hurdle has been cleared, proving constitutional harm is even more difficult, as the succeeding sections will show.

\section{B. Problems with an Equal Protection Claim}

Assuming that standing to sue is established, the obvious way to bring a claim against a search or seizure motivated by race is to claim that the search was unreasonable under the Fourth Amendment. However, the Supreme Court's unanimous opinion in Whren v. United States ${ }^{114}$ effectively closed this road. There, Justice Scalia wrote that "the constitutional basis for objecting to intentionally discriminatory application of laws is the Equal Protection Clause, not the Fourth Amendment. Subjective intentions play no role in ordinary, probable-cause Fourth Amendment analysis."

However, bringing suit under the Equal Protection Clause is extremely difficult. To prove that a procedure such as racial profiling has an unconstitutionally disparate impact upon minorities, a plaintiff

\footnotetext{
111. Id.

112. See also Anderson v. Cornejo, No. 97 C 7556, 1999 WL 258501, at*1-*2 (N.D. Ill. Apr. 21, 1999) (holding that Lyons is distinguished when 47 African-American women comprise the class).

113. See also Hodgers-Durgin v. De La Vina, 199 F.3d 1037, 1041-45 (9th Cir. 1999) (holding that Lyons does not command a lack of standing because "plaintiffs did nothing illegal to prompt the stops by the Border Patrol," but ultimately denying equitable relief out of federalism and comity concerns); Anderson, 1999 WL 258501, at *2 (holding that Lyons was distinguishable because "[h]ere, plaintiffs do not have to engage in illegal conduct to be subjected to searches").

114. 517 U.S. 806 (1996).

115. Id. at 813. For a more in-depth discussion of Whren, see infra notes 185-204 and accompanying text.
} 
must prove not only that such disparate impact exists, but that it is the result of intentional discrimination. ${ }^{116}$ A claim of selective prosecution is no easier to make, because a plaintiff must prove not only that prosecutors singled her out based upon her race, but also that other similarly situated whites were not prosecuted. ${ }^{117}$ Seemingly convincing statistical evidence also seems to be of little help in proving a case-a plaintiff must still prove that the statistical disparity is caused by racial animus. ${ }^{118}$

While there may be much sense in most of these doctrines, ${ }^{119}$ this test has nonetheless proved to be a stumbling block for cases at-

116. See Washington v. Davis, 426 U.S. 229, 242 (1976).

117. See United States v. Armstrong, 517 U.S. 456, $468-69$ (1996).

118. See McCleskey v. Kemp, 481 U.S. 279, 312-13 (1987) ("At most, the ... study indicates a discrepancy that appears to correlate with race.... [but] does not demonstrate a constitutionally significant risk of racial bias affecting the Georgia capital sentencing process."). The difficulty in meeting this requirement is also demonstrated by the Court's refusal to find an equal protection violation in Armstrong, 517 U.S. at 459, where all the defendants were black, and by Personnel Administrator v. Feeney, 442 U.S. 256, 270 (1979), where 98\% of all benefits from a government program flowed to men. Indeed, it appears that one of the few disparate impact cases where the Court took cognizance of statistical discrepancies was the very first one, Yick Wo v. Hopkins, 118 U.S. 356, 374 (1886). However, the departure there seems motivated more by the fact that the government could come up with absolutely no rationale, other than the racial one, for explaining why Chinese-owned laundromats were closed down, while those owned by whites were not. See id. (noting that "[n]o reason whatever, except the will of the supervisors, [was] assigned," and that "[n]o reason [for the disparate impact was] shown").

119. Requiring some evidence of an intent to discriminate as part of a prima facie case for a disparate impact claim is almost necessary for modern government to function; in a racially stratified society, almost everything, from social security disbursements to sickle-cell anemia research, will disproportionately affect minorities. See Crump, supra note 45, at 291. Moreover, allowing claims of selective prosecution to proceed with a lower bar risks forcing the prosecution to waste resources and turn over their strategy. See Armstrong, 517 U.S. at 468. Finally, as the McClesky Court observed, see supra note 118, and the analysis of racial profiling statistics cited above in supra note 45 demonstrates, statistics are easily manipulated. They only show correlations between different variables; standing alone they are of little use in proving causation. Even in a properly controlled experiment, correlations between two variables can mean any one of four things: (1) A caused B ("The sun rising makes the rooster crow"); (2) B caused A ("The rooster crowing makes the sun rise"); (3) outside factor C caused both A and B ("God makes both the rooster crow and the sun rise"); or (4) there is in fact no causal relationship between the two events, they just happen to follow each other. Thus, even properly controlled experiments (and what comprises a "properly controlled experiment" can be questionable) are of dubious use in litigation, which is of its nature a causal inquiry. Indeed, if grossly disproportionate statistics alone were enough to form the basis for a constitutional challenge, the death penalty would have been thrown out long ago on equal protection grounds-for being disproportionately applied to men. See Stephen B. Bright et al., Conference: The Death Penalty in the Twenty-First Century, 45 AM. U. L. REV. 239, 267 (1995) ("The big disproportion is not with defendants who are in poverty or defendants who have low IQs or with black defendants. By far, the greatest disproportion in the percentage of people on death row is men. . . [N]inetyeight percent of [death-row inmates] are men."); Nancy Levit, Feminism for Men: Legal Ideology and the Construction of Maleness, 43 UCLA L. REV. 1037, 1058-59 (1996) (noting that 
tempting to survive motions to dismiss and will likely continue to create a stumbling block for those few cases that survived standing as they hobble toward summary judgment. For example, while the Gerald court initially held that the pleadings alleged sufficient facts to support a claim against the trooper defendants, ${ }^{120}$ it expressed doubt about the case surviving a motion for summary judgment. As the court noted, "Plaintiffs will be required to present sufficient evidence to support this inference [that the stop was racially motivated] at a subsequent stage of this litigation." 221 The court followed this up by referring to Washington $v$. Vogel, ${ }^{122}$ a case that was dismissed at the summary judgment phase. ${ }^{123}$ Indeed, it seems hard to imagine facts that would prove that Troopers Perry and Knoke were motivated by racial animus; under Armstrong ${ }^{124}$ and McCleskey, ${ }^{125}$ even fairly compelling statistics that the troopers regularly pulled over blacks signifi-

\footnotetext{
"[t]he percentage of men on death row disproportionately exceeds the percentage of deatheligible offenses committed by men").

120. The court did not, however, fully consider the question of a racially discriminatory custom or practice against the non-trooper defendants. See Gerald v. Department of Pub. Safety, No. CIV 99-676-R, slip op. at 11 (W.D. Okla. Dec. 21, 1999) (granting motion to dismiss in part and denying motion to dismiss in part regarding the vicarious defendants). In addition, the court ultimately dismissed the equal protection claim against the trooper defendants under the Tenth Circuit's heightened pleading standard. See id. at 18-19 (granting motion to dismiss in part and denying motion to dismiss in part regarding the trooper defendants); see also Brief in Support of Motion to Dismiss by the Individual Defendants at 18, Gerald v. Department of Pub. Safety (No. CIV 99-676-R) (W.D. Okla. 1999). Since police officers often enjoy qualified immunity for their official actions, some circuits, including the Tenth Circuit, require more thorough pleadings for cases involving these defenses. See, e.g., Pueblo Neighborhood Health Cntrs. v. Losavio, 847 F.2d 642, 645-46 (10th Cir. 1988) (explaining the unique nature of the immunity defense); Elliott v. Perez, 751 F.2d 1472, 1473 (5th Cir. 1985) ("In cases against governmental officials involving the likely defense of immunity we require of trial judges that they demand that the plaintiff's complaint state with factual detail and particularity the basis for the claim which necessarily includes why the defendant-official cannot successfully maintain the defense of immunity."); see also Harlow v. Fitzgerald, 457 U.S. 800, 818 (1982) (establishing that, to rebut a qualified immunity defense, the plaintiff must identify a clearly established statutory or constitutional right of which a reasonable person would have known, and then allege facts to show that the defendant's conduct violated that right). In the Tenth Circuit, the heightened standard requires plaintiffs to plead "specific, non-conclusory allegations of fact sufficient to allow the district court to determine that those facts, if proved, demonstrate that the actions taken were not objectively reasonable in light of the clearly established law." Breidenbach v. Bolish, 126 F.3d 1288, 1293 (10th Cir. 1997).

121. Gerald, No. CIV. 99-676-R, slip op. at 9 (granting motion to dismiss in part and denying motion to dismiss in part regarding the trooper defendants).

122. 880 F. Supp. 1542 (M.D. Fla. 1995), aff'd, 106 F.3d 415 (11th Cir. 1997).

123. See id. at 1545.

124. United States v. Armstrong, 517 U.S. 456 (1996).

125. McCleksey v. Kemp, 481 U.S. 279 (1987).
} 
cantly more often than whites likely would fail to prove a sufficient case to survive summary judgment. ${ }^{126}$

Indeed, this exact difficulty was encountered in Washington $v$. Vogel. There, defendants went so far as to introduce expert testimony interpreting the series of videotaped stops. ${ }^{127}$ The court was not impressed, writing that "the jury could not reasonably draw any conclusions, relevant to [the plaintiffs], from the fact that greater than $60 \%$ of stops on existing videotapes were of blacks." ${ }^{128}$

Similar outcomes have plagued other "driving while black" cases. ${ }^{129}$ In Brown v. Ellendale Police Department, ${ }^{130}$ a section 1983 case factually similar to Gerald, ${ }^{131}$ the court granted summary judgment against the plaintiff, noting that a "nonmoving party "cannot rely upon conclusory allegations in its pleadings or in memoranda and briefs." "132 Thus, the plaintiff's allegations that he had been pulled over because of his race, supported by anecdotal evidence of racially motivated stops, failed to constitute "evidence from which a rational factfinder could conclude that the Ellendale Police have an official policy or custom of stopping and searching African-American drivers." 133

National Congress initially suffered a similar fate. ${ }^{134}$ There, the court, citing Armstrong, ruled that the plaintiffs had not succeeded in sufficiently alleging an equal protection violation, and it refused to

126. See supra note 118.

127. See Washington, 880 F. Supp. at 1544.

128. Id. at 1544-45. In a separate ruling, the court held the expert testimony inadmissible due to serious questions about the methodology. See Washington v. Vogel, 880 F. Supp. 1545, 1547-48 (M.D. Fla. 1995)

129. See Chavez v. Illinois State Police, 27 F. Supp. 2d 1053, 1067 (N.D. Ill. 1998) ("The plaintiff's arguments are based on the same flawed premise which was asserted and rejected by the Supreme Court in Armstrong."). All of this bodes poorly for National Congress for Puerto Rican Rights v. City of New York, 75 F. Supp. 2d 154 (S.D.N.Y. 1999), which is one of the only live cases to have survived the pleadings stage. However, that case was brought under Title VI of the Civil Rights Act of 1964, 42 U.S.C. \$ 2000d (1994), and therefore does not contain the same standards required of section 1983 cases alleging constitutional violations. See National Congress, 75 F. Supp. 2d at 158.

130. No. 97-54-SLR, 1999 U.S. Dist. LEXIS 5053 (D. Del. Mar. 31, 1999).

131. See id. at $* 3$ (noting alleged nervousness and disputing the facts of the encounter).

132. Id. at*8 (quoting Pastore v. Bell Tel. Co., 24 F.3d 508, 511 (3d Cir. 1994)).

133. Id. at *10. This evidence was similar to that offered by Gerald, and described above. See supra note 82 and accompanying text.

134. The case, however, was eventually reinstated due to a unique ruling of the Second Circuit. See National Congress for Puerto Rican Rights v. City of New York, 191 F.R.D. 51, 54 (S.D.N.Y. 1999) (denying summary judgment where the plaintiff alleged a policy containing "express, racial classification" but did not allege the "existence of similarly situated nonminority individuals" (citing Brown v. Oneonta, 195 F.3d 111 (2d Cir. 1999))). 
distinguish between selective prosecution and selective arrest cases. ${ }^{135}$ Moreover, the court made very clear that simply proving that the vast majority of those prosecuted were black or Hispanic would not suffice to maintain an equal protection case. ${ }^{136}$ The court concluded that "[w]ithout a showing of different treatment of similarly situated persons, either through statistical or other evidence, plaintiffs' Equal Protection claim is dismissed." 137

Thus, even if the initial standing obstacle is surmounted, profiling cases are likely to be stripped of their racial component, either at the outset or at the summary judgment phase. However, as the next section will show, even if substantial evidence exists that the stop was racially motivated, there is little likelihood that the plaintiff will ever see a verdict in his favor.

\section{Problems with the "Perfect Case"}

Assume, for the moment, that a police officer stops an individual, searches his car, and seizes contraband (or, for that matter, does not seize anything and is sued under section 1983). During depositions in the ensuing litigation, the police officer admits that she used a racial profile to decide to stop the plaintiff (though we must assume that she states that it was not the only factor in her decision to detain the suspect), that she customarily does so, and that she will continue to do so in the future. This would seem to present a "slam-dunk" case for a plaintiff in a section 1983 suit or for a defendant charging that his evidence should be suppressed.

Surprisingly, however, the bulk of authority suggests that, even under these circumstances, a suit would not be successful. In United States $v$. Weaver, ${ }^{138}$ a DEA agent stopped the defendant because he was " a 'roughly dressed' young black male who was carrying two bags and walking rapidly, almost running, down the concourse." encounter, Weaver was searched and found carrying crack cocaine, a smoking pipe, and over $\$ 2500 .^{140}$ However, rather than decrying the officer's use of race, the court stated that:

135. See National Congress for Puerto Rican Rights v. City of New York, 75 F. Supp. 2d 154, 167 (S.D.N.Y. 1999).

136. See id.

137. Id.

138. 966 F.2d 391 (8th Cir. 1992).

139. Id. at 392 (emphasis added); see also id. at 394 (describing DEA Officer Hicks's contention that the defendant's race formed part of his reasonable, articulable suspicion).

140. See id. at 393. 
We agree with the dissent that large groups of our citizens should not be regarded by law enforcement officers as presumptively criminal based upon their race. We would not hesitate to hold that a solely race-based suspicion of drug courier status would not pass constitutional muster.... As it is, however, facts are not to be ignored simply because they may be unpleasant-and the unpleasant fact in this case is that Hicks had knowledge... that young male members of black Los Angeles gangs were flooding the Kansas City area with cocaine. To that extent, then, race, when coupled with the other factors Hicks relied upon, was a factor in the decision to approach and ultimately detain Weaver. We wish it were otherwise, but we take the facts as they are presented to us, not as we would like them to be. ${ }^{141}$

Even the dissent, to which the majority referred, offered, at best, half-hearted concerns about the agent's reliance upon race. Chief Judge Morris Sheppard Arnold wrote that he was "not prepared to say that [race] could never be relevant." ${ }^{142} \mathrm{He}$ was concerned only that sufficient evidence justifying the profile had not yet been proffered. ${ }^{143}$ Thus, the members of the three-judge panel agreed that race could play a role in forming a reasonable articulable suspicion to detain a suspect-the only difference between them was over what type of evidence would be needed to support such a use of race.

Weaver does not stand alone. In United States $v$. Coleman, ${ }^{144}$ a black male was detained in an airport, and, after attempting unsuccessfully to flee and discard the contraband he was carrying, was arrested for possession of a controlled substance. ${ }^{145}$ At trial, the DEA agent expressly testified that he stopped Coleman on the basis "(1) that the defendant was coming from Los Angeles, (2) that he appeared to have no luggage with him, and (3) that he was black." ${ }^{, 16} \mathrm{Al}$ though the court held that the stop was not founded upon a reasonable suspicion and hence granted the motion to suppress, it rejected the argument that use of race was an inappropriate factor in justifying a stop. As the court wrote, "While ethnic background and, similarly, race are not features which can alone justify an investigative stop, they are one factor which may be taken into account, together with

141. Id. at 394 n.2.

142. Id. at 397 (Arnold, C.J., dissenting).

143. See id.

144. 450 F. Supp. 433 (E.D. Mich. 1978).

145. See id. at 435-36.

146. Id. at 439 . 
other pertinent circumstances ... . ${ }^{147}$ In United States v. Harvey, ${ }^{148}$ an officer was so bold as to state in court that "if the occupants had not been African Americans, he would not have stopped the car." ${ }^{\text {"149 }}$ A spirited dissent from Judge Keith notwithstanding, ${ }^{150}$ the court in Harvey refused to overturn the defendant's conviction; indeed, the majority failed even to mention the use of race in the officer's decision to detain Harvey. This pattern has been more or less consistently repeated in state and federal courts throughout the country. ${ }^{151}$ Even the Supreme Court has ruled that, at least in the context of border patrols, race may be used to justify a stop, so long as it is not the only factor justifying the stop. ${ }^{152}$

\footnotetext{
147. Id. at 439 n.7.

148. 16 F.3d 109 (6th Cir. 1994).

149. Id. at 113-14.

150. Judge Keith hardly pulled any punches when he wrote:
}

Equal Protection principles absolutely and categorically prohibit state actors from using race to differentiate between motorists. Yet, the majority acquiesces to an officer's substitution of race for probable cause and essentially licenses the state to discriminate. Moreover, the majority states race-based motivation is irrelevant under these or any circumstances. Not only is the officer's race-based motivation relevant, it is patently unconstitutional.

Id. at 114 (Keith, J., dissenting). Keith went on to launch an almost personal attack upon the majority, writing, "[t]he majority's willful disregard of the flagrant discriminatory treatment in this case endorses a system where one set of traffic regulations exist for African-Americans, like myself, and a more lenient set exists for white Americans." Id.

151. See, e.g., United States v. Harrington, 636 F.2d 1182, 1184 (9th Cir. 1980) (finding significance in the fact that a "Mexican" male visited defendant's hotel room); United States v. Collins, 532 F.2d 79, 82 (8th Cir. 1976) (rejecting the defendant's claim that his skin color is irrelevant because "the color of a person's skin, be it black or white, is an identifying factor which, while insufficient by itself, assists the police in narrowing the scope of their identification procedure"); State v. Dean, 543 P.2d 425, 427 (Ariz. 1975) ("[T]he fact that a person is obviously out of place in a particular neighborhood is one of several factors that may be considered by an officer and the court in determining whether an investigation and detention is reasonable and therefore lawful."); see also United States v. Richard, 535 F.2d 246, 248-49 (3d Cir. 1976) (holding that, even though an informant may be using race as the only basis for suspicion, if police couple this with other factors, a reasonable articulable suspicion to initiate a Terry stop may be justified); State v. Barber, 823 P.2d 1068, 1075 (Wash. 1992) (noting that race may sometimes be a factor in a stop). Even a fairly recent case seems to have looked the other way regarding charges of racial profiling. See United States v. Stone, 73 F. Supp. 2d 441, 447 (S.D.N.Y. 1999) ("Nevertheless, even assuming that the defendant was singled out for closer inspection on the basis of his race in concert with the time and the location in which he walked, I am satisfied that the officers' subsequent actions fully comply with the Fourth Amendment[] ....").

152. See United States v. Martinez-Fuerte, 428 U.S. 543, 563 (1976) ("[E]ven if it be assumed that such referrals [to the secondary checkpoint] are made largely on the basis of apparent Mexican ancestry, we perceive no constitutional violation."); id. at 564 n.17 ("Thus, to the extent that the Border Patrol relies on apparent Mexican ancestry at this checkpoint, that reliance clearly is relevant to the law enforcement need to be served.") (citation omitted); United States v. Brignoni-Ponce, 422 U.S. 873, 886-87 (1975) ("The likelihood that any given person of Mexican ancestry is an alien is high enough to make Mexican appearance a relevant factor, but standing alone it does not justify stopping all Mexican-Americans to ask if they are aliens."). 
To be sure, courts are not universal in their acceptance of the practice. ${ }^{153}$ However, the weight of authority indicates that race is an acceptable factor in probable cause analysis, so long as it is not the only factor. If police can come up with non-racial justifications for their actions, such as those found in the drug courier profile, the defendant will have no legal recourse on the profiling point. This series of holdings, combined with Whren's holding that the subjective intentions of officers will no longer be probed, seems to imply that it will be a long time before many racial profiling cases reach the jury, much less before they are successful.

\section{WHAT IS TO BE DONE?}

The fact that the status quo will likely yield little progress in remedying or ending the practice of racial profiling naturally gives rise to a question: how should the status quo be changed, if at all, to put an end to the practice? This part of the Note attempts to answer that question by examining the costs and benefits of ending profiling. While admitting that the question is closer than many authors assume, the Note determines that the practical and moral benefits of ending profiling outweigh the costs. The Note then suggests a possible solution to those concerns, concluding that a search or seizure based even in part upon race should be unreasonable under the Fourth Amendment.

153. See, e.g., City of St. Paul v. Uber, 450 N.W.2d 623, 628 (Minn. Ct. App. 1990) (reversing a conviction where part of the officers' suspicion stemmed from the defendant's being a white person in a black neighborhood); Lowery v. Commonwealth, 388 S.E.2d 265, 267 (Va. Ct. App. 1990) ("While we agree that the State has a substantial interest in apprehending drug traffickers, we do not agree with the Commonwealth's argument that this type of racial classification is necessary to accomplish that objective. A person's race or national origin does not indicate a propensity to traffic in drugs."); State v. Barber, 823 P.2d 1068, 1075 (Wash. 1992) ("Distinctions between citizens solely because of their ancestry are odious to a free people whose institutions are founded upon the doctrine of equality."); see also United States v. Montero-Camargo, 208 F.3d 1122, 1131-36 (9th Cir. 2000) (holding that language justifying the use of race at border stops in Brignoni-Ponce was "dictum," that circumstances and subsequent Supreme Court decisions had changed to justify abrogation of that "dictum," and abrogating that "dictum"); State v. Ballard, 752 A.2d 735, 752 (N.J. Super. Ct. App. Div. 2000) (permitting defendants to obtain discovery concerning state police practices resulting in racial profiling); $c f$. Washington v. Lambert, 98 F.3d 1181 passim (9th Cir. 1996) (condemning repeatedly the indignities suffered by African-Americans at the hands of law enforcement officials); Martinez v. Village of Mount Prospect, 92 F. Supp. 2d 780, 782-85 (N.D. Ill. 2000) (approving a settlement agreement, while offering three pages of policy reasons for allowing more racial profiling cases to proceed). 


\section{A. The Costs and Benefits of Action and Inaction}

Most of the commentary on profiling, to date, borders on polemical; there has been little careful debate over the costs and benefits of profiling. However, the case can be made that ending racial profiling would deprive police of a potentially effective tool in combating crime. In addition, because of the essentially intra-racial nature of crime in America today, these costs would likely be borne by the very minorities that anti-profiling measures aim to protect.

Scholars describing the costs of ending profiling rely on the argument that, because African Americans commit crimes at a higher rate than the general population, police are justified in being more suspicious of them, and that doing so is simply effective police work. In the words of Dinesh D'Souza, profiling is "rational discrimination." ${ }^{154}$ This is essentially the argument made by LAPD Chief Bernard Parks, himself an African American. Indeed, many AfricanAmerican police officers themselves frequently support profiling for exactly this reason. ${ }^{155}$ As Parks stated, "It's not the fault of the police when they stop minority males or put them in jail. ... In my mind it is not a great revelation that if officers are looking for criminal activity, they're going to look at the kind of people who are listed on crime reports." ${ }^{156}$ Parks also explains how this rationale is not always directed at African Americans:

We have an issue of violent crime against jewelry salespeople....

The predominant suspects are Colombians. We don't find MexicanAmericans, or blacks, or other immigrants. It's a collection of several hundred Colombians who commit this crime. If you see six in a car in front of the Jewelry Mart, and they're waiting and watching people with briefcases, should we play the percentages and follow them? It's common sense. ${ }^{157}$

Few would fault a woman walking alone at night who does not cross the street when another woman approaches, but who does when a man approaches. Doing otherwise might rob her of an effective means of protecting herself. So, the argument goes, why would we fault her for similarly using race as a proxy for criminality, and for

154. D'SoUZA, supra note 12, at 285.

155. See id.

156. Bob Herbert \& Jeffrey Goldberg, Police and Racial Profiling: Is Police Tactic Fair?, N.Y. Times UPFRONT, Sept. 6, 1999, at 36 (quoting Bernard Parks).

157. Kennedy, supra note 12, at 30 (quoting Bernard Parks). 
being more likely to cross the street when a black man approaches than a white man $?^{158}$ To complete the analogy, why should we force society to bear the costs of playing the odds? $?^{159}$ While the Constitution frowns upon the use of racial categories, it "is not a suicide pact" that requires that the innocent never be stopped.

Some respond to these arguments by disputing the costs of ending profiling. For example, David Cole argues that, although blacks actually use drugs roughly in proportion to their share of the population $(14 \%)$, they account for $35 \%$ of those arrested for possession, $55 \%$ of those convicted, and $74 \%$ of those sentenced for drug use. ${ }^{161}$ In Cole's mind, racial profiling creates, rather than justifies, the disparity; because officers are looking for blacks, they find black lawbreakers more frequently, thus skewing the statistics. Another scholar put it more bluntly: "If the police decided that studying law was suspicious behavior, and ... conducted more stops of law students, the number of law students who get busted for drug offenses and other crimes would rise appreciably." 162 Thus, since racial profiling is completely ineffective in these scholars' view, there would be little if any cost to ending it.

However well-intentioned these arguments may be, it seems unlikely that these disparities are entirely due to profiling and stereo-

158. Indeed, this is precisely the line of reasoning that troubled Jesse Jackson in his (in)famous 1993 quote. See supra note 1 and accompanying text. There is, however, some difference between a private actor behaving in such a manner and an agent of the state doing so. Indeed, Professor Kennedy reluctantly seems to excuse the former type of behavior, while condemning the latter. See RANDALl KENNEDY, RACE, CRIME, AND THE LAW 165-66 (1997).

159. One other argument is that, by condemning racial profiling, we threaten effective means of non-racial profiling as well. John Marcello worries that reforming the system to decrease the use of profiling would make officers second-guess themselves too frequently, resulting in the escape of guilty suspects who would otherwise have been caught. See Marcello, supra note 12 , at 25 ("Should the police ignore passengers exhibiting these characteristics because their race makes the police afraid to act lest they might be accused of racism?").

160. Kennedy v. Mendoza-Martinez, 372 U.S. 144, 160 (1963); see also Terminiello v. Chicago, 337 U.S. 1, 37 (1949) (Jackson, J., dissenting) ("There is danger that, if the Court does not temper its doctrinaire logic with a little practical wisdom, it will convert the constitutional Bill of Rights into a suicide pact.”).

161. See Cole, supra note 27, at 1075; see also Angela J. Davis, Benign Neglect of Racism in the Criminal Justice System, 94 MICH. L. REV. 1660, 1661 n.5 (1996) (book review) (noting the role that race plays in police decisions to stop or detain a suspect).

162. Paul Butler, Starr Is to Clinton as Regular Prosecutors Are to Blacks, 40 B.C. L. REV. 705, 709 (1999); see also Sean Hecker, Race and Pretextual Traffic Stops: An Expanded Role for Civilian Review Boards, 28 Colum. HuM. RTS. L. REV. 551, 567 (1997) ("If police target motorists based, at least in part, on the motorist's race, they may create a self-fulfilling prophecyrace will become a probative factor because by targeting minorities for stops, a disproportionate percentage of those with drugs will be minorities."). 
typing. For example, assuming Professor Cole's statistics are in fact accurate, they nonetheless fail to include drug-related crimes, such as drug trafficking. If a racial disparity occurs there, then profiling would still retain its rationality. ${ }^{163}$ In the same vein, factors such as the sentencing disparity between crack cocaine and powder cocaine-a disparity that now negatively affects blacks ${ }^{164}$ (and that was initially pushed for by many members of the Black Congressional Caucus due to the effect crack had upon inner cities ${ }^{165}$ ) - may account for the differing rates. Regardless of whether one takes a far left view and believes that crime is a function of social oppression, ${ }^{166}$ a more centrist view that crime is a result of poverty, ${ }^{167}$ or a more conservative view that crime is related to familial breakdown, ${ }^{168}$ one would expect to see higher rates of crime among blacks than among whites, simply by virtue of the makeup of our society. ${ }^{169}$

163. This says nothing of the possibility that our current drug strategy of prosecuting drug dealers as opposed to kingpins should be re-examined, if for no other reason than the racial implications of the strategy. It only states that, given our current strategy, profiling may be a rational means to achieving those ends.

164. Compare United States v. Armstrong, 517 U.S. 456, 476-483 (1996) (Stevens, J., dissenting) (describing disparities created by the crack/cocaine dichotomy), with Randall Kennedy, A Response to Professor Cole's "Paradox of Race and Crime," 83 GEO. L.J. 2573, 2573-76 (1995) (noting the existence of the crack/cocaine disparity and explaining a possible rational basis supporting its constitutionality).

165. See 132 CONG. REC. E30,150 (1986) (statement of Rep. Rangle) (noting support for a "crack down on crack" after observing its insidious addition to the drug scene and its significant effects). Representative Walden noted that:

Crack usage is the evidence that our society may in fact be losing control of itself. For those of us who are black this self-inflicted pain is the worse oppression we have known since slavery.... It is so devastating that nothing short of a declaration of all out war will suffice.

132 CONG. REC. H20,739 (1986) (statement of Rep. Walden).

166. See Paul Butler, The Evil of American Criminal Justice: A Reply, 44 UCLA L. REv. 143, 147 n.14 (1996) (noting that the root causes of crime include racism and poverty).

167. See DAVID BAZELON, QUESTIONING AUTHORITY: JUSTICE AND CRIMINAL LAw 17 (1987) (noting that most criminals come from the bottom of the socio-economic ladder and are born into families struggling to survive).

168. See generally John J. Dilulio, Jr., The Coming of the Super-Predators, WEeKLY STANDARD, Nov. 27, 1995, at 23 (citing breakdowns in family ties and religion as leading causes of increased criminality).

169. In a way, these chicken-or-the-egg-type arguments underscore the difficulty in relying upon statistics discussed supra notes 45 and 119. It may well be that profiling causes the sentencing disparity, that the disparity causes profiling, or that underlying racism causes both. The only way to really sort out these varying causal relationships is to examine underlying causal theories. The fact that most of these theories would at least somewhat predict higher rates of certain crimes in the black community is ultimately what leads me to accept Kennedy's views. 
In the end, Professor Randall Kennedy, a self-described Leftist, ${ }^{170}$ is probably correct that there is simply "no use pretending that blacks and whites commit crimes ... in exact proportion to their respective shares of the population." ${ }^{\text {"171 }}$ While racial profiling probably does distort the arrest rates somewhat vis-à-vis blacks and whites, it seems that racial profiling is, to a certain extent, a rational reaction to the current realities of society, and that eliminating it would exact a toll upon society by removing a somewhat-effective crime-fighting technique. Opposition to this argument stems from an understandable aversion to conceding arguments that can be and are used by those with more malevolent motives to denigrate minorities. ${ }^{172}$ Kennedy is correct, however, when he argues that "[d] erogatory attacks cannot be responded to effectively, however, by denying facts that cannot sensibly be denied." ${ }^{, 173}$ Denying such facts, moreover, probably retards efforts to combat such racist arguments, as well as the search for effective crime-fighting techniques, by forcing people to take more polarized positions than they normally would (as does taking the equally indefensible position that profiling does not occur).

Ironically, the costs of ending profiling would fall disproportionately upon the very people anti-profiling laws would intend to protect. If drug-related crime is disproportionately committed by African Americans, that crime is also disproportionately committed against African Americans. Currently, more blacks are killed by blacks on any particular day than are killed by whites in an entire week $;^{174}$

170. Kennedy's beliefs, which initially caused a stir in the academic community, mark an admitted break with his previous views and with what he is beginning to see as the harmful effects of Leftist orthodoxy. In Kennedy's words,

My thinking has indeed evolved since I wrote ... earlier pieces. An important part of this change has been a slow but steady apprehension that across a wide array of areas, colleagues of the Left (of which I still consider myself a part) are taking morally dubious and politically ineffectual positions that contribute to the stymieing of muchneeded efforts to better our society.

Kennedy, supra note 164, at 2578.

171. Kennedy, supra note 12, at 32; see also id. ("Statistics abundantly confirm that African Americans—and particularly young black men—commit a dramatically disproportionate share of street crime in the United States. This is a sociological fact, not a figment of the media's (or the police's) racist imagination.").

172. This counterargument was made explicit at a conference in which I participated for the Duke Black Law Students' Association. Several students raised concerns that validating such facts also might tend to validate people's stereotypes of blacks and give credence to some of the more virulent arguments pervading the racial debate in America. See Sean P. Trende, Remarks at Duke Black Law Students' Association Conference on Racial Profiling, "Boys in Blue, Men in Black: Police Brutality and D.W.B.” (Apr. 17, 2000).

173. KENNEDY, supra note 158, at 22.

174. See Jim SleEPER, Liberal RACISM 24 (1997). 
"crime afflicts African-Americans with a special vengeance." we are left with the vexing question of to what extent we should disavow a potentially effective crime-fighting technique when there is some rational basis for it, and when that technique potentially would help the same community it hurts. Or, as Kennedy puts it, "[i]n deciding whether rights have been infringed, however, courts should be careful to avoid conflating the interests of a subdivision of blacksblack suspects, defendants, or convicts - with the interests of blacks as a whole. ${ }^{176}$

However, if the Left is wrong in refusing to weigh the costs of ending profiling, the Right is derelict in ignoring the costs of allowing profiling to continue. Not the least of these costs is the psychological costs of blacks being reminded of their history of, at best, second-class citizenship. The literature is replete with examples of blacks changing their behavior in order to avoid being pulled over by police officers. Black men sometimes will avoid renting sports cars-as will some white men - or will alter their style of dress to avoid being stopped. ${ }^{17}$ Black parents sometimes go to great lengths to teach their children how to act if they are pulled over. ${ }^{178}$

More concretely, the existence of profiling and the press attention given to the practice only serve to increase tensions between mi-

175. Randall Kennedy, The State, Criminal Law, and Racial Discrimination: A Comment, 107 HARV. L. REV. 1255, 1255 (1994).

176. KENNEDY, supra note 158, at 11; see also id. at 10 ("But are black communities hurt by police crackdowns on violent gangs or helped by the destabilization of gangs that terrorize those who live in their midst?"). Indeed, Gallup polling indicates that $82 \%$ of African-Americans believe that local courts should be harder on criminals, $75 \%$ favor putting more police on the street, and $68 \%$ believe that more prisons should be built to house criminals. See William A. Galston \& David T. Wasserman, Race, Crime, and the Law, WILSON Q., Mar. 1, 1997, at 100. David Cole's response to this is worth mentioning. Cole argues that under Kennedy's reasoning, a law that made crack laws applicable only to African-Americans would be justified because the burden of crack upon African-American communities probably outweighs the cost of such a law. See David Cole, The Paradox of Race and Crime: A Comment on Randall Kennedy's "Politics of Distinction," 83 GEO. L.J. 2547, 2551 (1995). This overlooks the fact that Kennedy's balancing argument is strictly limited to situations where laws have disparate impacts, and not to situations where discrimination is explicitly created by the state. See Kennedy, supra note 175, at 1256-57.

177. See Davis, supra note 8 , at 425 .

178. See Rash of Racial Profiling Forces Black Parents to Prepare Young Drivers For Police Stops, JET, Mar. 29, 1999, at 7 (describing one black parent who tells her son not to travel with anything that might be considered contraband and to be "extremely cooperative" with police officers by answering all questions while keeping his hands in "full view"). Again, it is likely that white parents do the same with their children, though perhaps with a lesser sense of urgency. 
norities and police. ${ }^{179}$ As Justice O'Connor noted, "classifications based on race carry a danger of stigmatic harm. Unless they are strictly reserved for remedial settings, they may in fact promote notions of racial inferiority and lead to a politics of racial hostility." 180

In the end, though, there is one cost to profiling that trumps the other concerns: the moral cost. Although people do use various proxies, of which race is only one, to prejudge the likelihood of other people to commit certain acts, criminal or otherwise, the especiallyugly use of racial categorizations in America has slowly brought about a consensus that "[r]ace is different."

The Equal Protection Clause of the Fourteenth Amendment is the explicit constitutional embodiment of this consensus. While the vast majority of categorizations pass constitutional muster if they are simply rational, ${ }^{182}$ categorizations based upon race are acceptable only when they are narrowly tailored toward achieving a compelling governmental interest. ${ }^{183}$ Part III.B of this Note is dedicated to establishing that, while these values are explicitly found in the Equal Protection clause, they should also affect our definition of an "unreasonable" search under the Fourth Amendment.

\section{B. Minimizing the Costs, Maximizing the Benefits: Adopting a Rule Against Racially Motivated Searches}

Several possible solutions to ending racial profiling have been proposed, ranging from modest attempts to change police culture to radical changes in Supreme Court case law. ${ }^{184}$ The optimal solution

179. See Drummon, supra note 58; Harris, supra note 45, at 308-09 ("If the 'driving while black' problem is not addressed, community policing will be made much more difficult and may even fail.").

180. City of Richmond v. J.A. Croson Co., 488 U.S. 469, 493 (1989).

181. KENNEDY, supra note 158, at 146; see also COLE, supra note 31, at 42 ("But that it may be rational does not make it right.").

182. See, e.g., San Antonio Indep. Sch. Dist. v. Rodriguez, 411 U.S. 1, 16-17 (1973).

183. See, e.g., Adarand Constr. Co. v. Pena, 515 U.S. 200, 224-25 (1995) (““'When classifications] touch upon an individual's race or ethnic background, he is entitled to a judicial determination that the burden he is asked to bear on that basis is precisely tailored to serve a compelling governmental interest. The Constitution guarantees that right to every person regardless of his background." (quoting Shelley v. Kraemer, 334 U.S. 1, 22 (1948)). Of course, categorizations involving "fundamental rights" guaranteed by the Constitution are also subject to strict scrutiny. See, e.g., Shapiro v. Thompson, 394 U.S. 618, 638 (1969) (invalidating a waiting-period requirement for out-of-state welfare applicants as a violation of the fundamental right of interstate movement).

184. Though there is much to say about the Court's standing jurisprudence, see, e.g., Gene Nichol, Jr., Rethinking Standing, 72 CAL. L. REV. 68, 100-01 (1982) (discussing the manipulation of the injury standard in order to satisfy standing requirements); Richard Fallon, Of Justiciabil- 
would be one that captures the moral and constitutional imperative of combating profiling described above and maximizes the benefits incurred while avoiding the costs. This section of the Note argues that one such solution would be to adopt a per se rule against racially motivated searches and seizures.

Currently, the main impediment to such a rule is the Court's holding in Whren v. United States. There, the Court held that searches should be governed by a test of whether a reasonable officer could have made a stop rather than whether he would have. From this, the Court concluded that "the constitutional basis for objecting to intentionally discriminatory application of laws is the Equal Protection Clause, not the Fourth Amendment." 185

Unlike most commentary on Whren, this Note does not necessarily disagree with the holding that gave rise to the latter statement. Thus, before describing precisely what the proposal does do, ${ }^{186}$ it is perhaps appropriate to begin this section by describing what the proposed solution does not do: it does not call for an absolute overruling of Whren.

In Whren, two African-American males were pulled over for pausing at a stop sign for an unusually long time, turning without signaling, and taking off at an unreasonable speed. ${ }^{187}$ When the vehicle was stopped, the detaining officer spotted two bags of crack cocaine in plain view. ${ }^{188}$ On appeal from their convictions on drug offenses, the defendants claimed that they were stopped simply because they were young black men in a Nissan Pathfinder, and that the stop was a mere pretext to allow the officers to search for drugs. ${ }^{189}$ In the course of making this claim, the defendants asked the Court to change the standard for determining whether a stop is reasonable from a test of whether an officer "could have" justified a stop to a subjective test of whether an reasonable officer "would have" done so. ${ }^{190}$

\footnotetext{
ity, Remedies, and Public Law Litigation, 59 N.Y.U. L. REV. 1, 1 (1984) (discussing the impact of Lyons on public law litigation), such a discussion is beyond the immediate scope of this note.

185. United States v. Whren, 517 U.S. 806, 813 (1996).

186. See infra notes 205-11 and accompanying text.

187. See Whren, 517 U.S. at 808.

188. See id. at 809.

189. See id. at 810 . Interestingly, it seems highly unlikely that the defendants could have prevailed on this claim, even if the Court had ruled that the officer's subjective intentions were relevant. Courts have consistently held that race may be a factor in the decision to detain a suspect as long as it is not the only factor. See supra notes 138-52 and accompanying text.

190. Whren, 517 U.S. at 811.
} 
A unanimous Court refused to adopt such a rule, holding that the subjective intentions of police officers were irrelevant for the purposes of a Fourth Amendment search and seizure. ${ }^{191}$ While this holding has drawn much criticism, ${ }^{192}$ in its broadest sense it is certainly correct. First, the decision is squarely in line with precedent, which has long shown a preference for objective tests of reasonableness. ${ }^{193}$ More importantly, the central question presented in Whren swept much more broadly than simply probing if race could be a factor in a detention. Rather, the Whren defendants raised the concern that the traffic codes as a whole were being used "as a means of investigating other law violations, as to which no probable cause ... exists,",194 and for special heightened scrutiny of traffic stops. ${ }^{195}$ Thus, the Whren defendants asked the Court to allow near-constant probing for any subjective motivations of a stop. By rejecting the defendants' contention, the Whren Court in essence simply noted that society has a right to enforce its laws. Officers should not be second-guessed for enforcing a law, such as the fifty-five mile-per-hour speed limit, when someone

191. See Whren, 517 U.S. at 813 ("Subjective intentions play no role in ordinary, probablecause Fourth Amendment analysis.").

192. Most of these attacks focus upon the central holding of Whren, that police officers may initiate a stop anytime for any violation of a state's motor vehicle code. These criticisms emphasize that, under Whren, it becomes very easy for a police officer to pull over just about anyone to go on a "fishing expedition" for indicia of drugs. David Harris notes that, given the level of detail present in most motor vehicle codes, most people can scarcely drive a few blocks without committing some infraction. See David A. Harris, Car Wars: The Fourth Amendment's Death on the Highway, 66 GEO. WASH. L. REV. 556, 559-61 (1998). For example, in many states, drivers can be stopped either for speeding or for driving unreasonably slowly. See Harris, supra note 8, at 558. In Utah, drivers must signal at least three seconds before turning. UTAH CODE ANN. § 41-6-69 (1993); Harris, supra note 8, at 558. In Maryland, a driver must signal at least 100 feet before changing lanes, may not slow down "suddenly," and may not drive without a functioning taillight, with insufficient rear-tag illumination, or with tread-bare tires. See Harris, supra note 8, at 558-59. Given the ease with which an officer may stop a suspect, it was hardly hyperbole for one police manual to boast "you can always get a guy legitimately on a traffic violation if you tail him for a while, and then a search can be made." Id. (quoting LAWRENCE F. TIFFANY ET AL., DETECTION OF CRIME 131 (1967)). Thus, from this point of view, Whren really can be seen as the embodiment of Justice Douglas's warning that Whren's progenitor, Terry v. Ohio, 392 U.S. 1 (1968), represented "a long step down the totalitarian path." Id. at 38 (Douglas, J., dissenting).

193. See, e.g., Scott v. United States, 436 U.S. 128, 137-38 (1978) (“[T]he fact that the officer does not have the state of mind which is hypothecated by the reasons which provide the legal justification for the officer's action does not invalidate the action taken as long as the circumstances, viewed objectively, justify that action."); Terry, 392 U.S. at 21 ("And in making that assessment it is imperative that the facts be judged against an objective standard ....").

194. Whren, 517 U.S. at 810.

195. See id. ("To avoid this danger ... the Fourth Amendment test for traffic stops should be, not the normal one... but rather, whether a police officer, acting reasonably, would have made the stop for the reason given."). 
has clearly broken it, even if the detaining officer hopes that he will gain probable cause for a search as a result of the stop. The Court made this idea explicit, writing that, "we are aware of no principle that would allow us to decide at what point a code of law becomes so expansive and so commonly violated that infraction itself can no longer be the ordinary measure of the lawfulness of enforcement." ${ }^{196}$ Society's laws may be so complex as to make them difficult to follow, and there may be situations where the arbitrary ways in which seemingly neutral laws are applied raises constitutional questions. ${ }^{197}$ But, in general, a legal regime that held that enforcing a clear violation of its laws necessarily opened an investigation into the whole panoply of potential subjective motivations of an officer would be a very strange one indeed.

Moreover, even assuming that an officer has a pretextual desire to eventually search a car lurking in the back of her head, Whren does not, as one commentator claims, stand for the proposition that such an officer "need only point to an inevitable traffic violation to avoid the Terry standard." 198 Traffic offenses do not automatically give rise to sufficient levels of suspicion to justify a search. ${ }^{199}$ Officers may not detain a person longer than needed to effectuate the purposes of the stop (e.g., issuing the citation), and, in general, detentions past that point in which a reasonable person would not feel free to leave re-

196. Id. at 818 .

197. Indeed, this is exactly the point of Justice Brennan's concurring opinion in Furman v. Georgia, 408 U.S. 238 (1972): when society enforces its laws in an arbitrary fashion, it may run afoul of the Eighth Amendment. See id. at 274 (Brennan, J., concurring); see also Yick Wo v. Hopkins, 118 U.S. 356, 373-74 (1886) ("Though the law itself be fair on its face and impartial in appearance, yet, if it is applied and administered by public authority with an evil eye and an unequal hand ... the denial of equal justice is still within the prohibition of the Constitution."). However, no one is contesting that the motor vehicle code as a whole is so arbitrarily applied as to constitute cruel and unusual punishment. Moreover, even Justice Brennan's language is limited to cases where the state is arbitrarily imposing a "severe punishment." Furman, 408 U.S. at 274 (Brennan, J., concurring). It seems hard to argue that the enforcement of traffic laws alone would constitute a "severe" punishment.

198. Hecker, supra note 162 , at 579.

199. See Knowles v. Iowa, 512 U.S. 113, 118-19 (1999) (disallowing a search incident to a traffic stop when a mere citation was issued); New York v. Belton, 453 U.S. 454, 462-63 (1981) (allowing a search of the passenger compartment of a car incident to an arrest); see also Gustafson v. Florida, 414 U.S. 260, 267 (1973) (Stewart, J., concurring) (suggesting that "a persuasive claim might have been made ... that the custodial arrest of the petitioner for a minor traffic offense violated his rights under the Fourth and Fourteenth Amendments"). But see Atwater v. City of Lago Vista, 195 F.3d 242 (5th Cir. 1999), cert. granted, 120 S. Ct. 2715 (2000) (reversing, on alternative grounds, a lower court's holding that an arrest made incident to a traffic citation is unreasonable under the Fourth Amendment). 
quire additional probable cause. ${ }^{200}$ Indeed, case law is replete with examples of courts suppressing evidence as the result of a traffic stop where an officer's belief that a person was a drug courier did not rise to the requisite level of reasonable suspicion. ${ }^{201}$ And it is important to remember-though it rarely is-that Whren never even rose to the level of a Terry stop; the drugs were spotted in plain view before the officer even had a chance to try to search the car. Likewise, Whren was not a marginal case where a petitioner had merely suspiciously "swerved" or stopped "suddenly." The Court noted this fact explicitly, writing that "[f] or the run-of-the-mine case, which this surely is, we think there is no realistic alternative to the traditional commonlaw rule that probable cause justifies a search and seizure." 202 In short, if a person is not so daft as to carry crack cocaine on his lap, and does not exhibit other suspicious traits, ${ }^{203}$ the average citizen will probably leave the incident with a deserved citation for breaking a law and little else..$^{204}$

Thus, Whren is correct that, under the Fourth Amendment, we should generally not go on fishing expeditions into an officer's subjective intentions. However, where Whren goes awry is in its rejection of the possibility of any racial claim under the Fourth Amendment. It is something of a non sequitur to say that because subjective motivations do not play a role in ordinary determinations of probable cause that the use of race can never be probed under objective standards of

200. See Florida v. Bostick, 501 U.S. 429, 433-37 (1991).

201. See, e.g., United States v. Collins, 200 F.3d 1196, 1197 (8th Cir. 2000) (holding that an officer did not have grounds to stop the defendant, but refusing to reverse the conviction since the defendant had independently justified his arrest by striking the officer); United States v. Sprinkle, 106 F.3d 613, 618-19 (4th Cir. 1997) (holding that spotting the defendant in a highcrime neighborhood, knowing the defendant had a criminal record, and observing the defendant hiding his face did not justify a Terry stop); United States v. Sundiata, 3 F. Supp. 2d 682, 689-90 (E.D. Va. 1998):

Even considering the additional factors of the lateness of the hour, and the proximity of the residence of a fugitive, collectively, these factors do not amount to a reasonable, articulable suspicion.... [nor was a Terry stop justified by] the subjective opinion of one officer present at the scene that a car left a parking stop "quickly."

202. Whren v. United States, 517 U.S. 806, 819 (1996). Indeed, most of the cases to which post-Whren critics have pointed also involve surprisingly clear-cut violations of the law. See, e.g., Hecker, supra note 162, at 581-83 (citing cases involving broken taillights, failing to signal a turn, and driving without a license plate light as evidence that the predicted ill effects of Whren "have already begun").

203. And here, courts of appeals have been rather good about imposing a reasonably high standard for a reasonably articulable suspicion. See supra note 201.

204. It seems a shame that a decision that affects the lives of normal people was made with facts involving extremely inept criminals, but this seems more often than not to be the case in criminal law. At any rate, the facts of Whren make it very easy to approve of the central holding. 
reasonableness. For example, what of a case such as Weaver, where the officer explicitly states that race was a factor in his decision to detain a suspect? $?^{205}$ Or what of Harvey, where the officer indicates that he would not have stopped the defendant if he had not been black? ${ }^{206}$ It seems perfectly reasonable to ask if an officer could reasonably make such stops.

More importantly, while the Fourth Amendment originally commanded an inquiry only into whether an officer could have reasonably made a stop, and no more, the Fourteenth Amendment requires (at least limited) inquiries into the motivations of government actors when suspect categories such as race are used. As a result of the Fourteenth Amendment, the government may not use the color of a person's skin to disadvantage a person in education, ${ }^{207}$ employment, ${ }^{208}$ or accommodations, ${ }^{209}$ even if the categorizations are used as part of the pursuit of other valid governmental goals. It seems to follow, then, that government officials should not be able to rely upon racial categorizations to enforce their laws through findings of probable cause based upon race, and that such findings should be invalid. By remaining true to the original understanding of both amendments, the Court's test should at a minimum read: could an officer have stopped the defendant without using race as a factor?

A series of examples might help clarify this. Assume, at step one, facts similar to Harvey: an African-American defendant is pulled over by an officer who admits that race was part of his determination of probable cause, and that probable cause would not have existed absent the officer's reliance upon race as an indicator. Under Weaver and Harvey, skin color would be treated as simply one of the many acceptable criteria upon which officers may rely-though, to be sure, it may not be the sole criterion upon which officers may rely. The proposal would eliminate race from the categories of acceptable factors to be relied upon by officers in determining whether a stop is rea-

205. See supra notes $138-43$ and accompanying text.

206. See supra notes 148-50 and accompanying text.

207. See, e.g., Brown v. Board of Educ., 347 U.S. 483, 495 (1954) (announcing that segregation in public education is a denial of the equal protection of the laws).

208. Cf., e.g., Turner v. Fouche, 396 U.S. 346, 362-63 (1970) (holding that a person may not be subjected to discriminatory treatment under the Fourteenth Amendment in seeking public office).

209. See, e.g., Burton v. Parking Auth., 365 U.S. 715, 716-17 (1961) (holding that a restaurant located in a public parking garage that excluded blacks violated the guarantees of the Equal Protection Clause). 
sonable. This would not be a large departure from Whren; by taking this step, the Court would simply define permissible objective factors for determining whether probable cause exists.

While disallowing the use of race as a factor would change the result in a few cases such as Harvey, where an officer admits that probable cause would not have existed absent the use of race, the proposal goes further. At step two, imagine that probable cause would have existed, but it is apparent, in a Yick Wo sense, that the officer's objective purpose was simply to harass African-American defendants. At this step, the proposal has no trouble holding that, consistent with the Equal Protection Clause, the officer objectively could not make the stop, since again, his objective purpose was to detain a suspect on the basis of race.

These two steps should give little pause; given the text of the Equal Protection Clause and the Supreme Court's subsequent jurisprudence, it seems clear that these blatant uses of racial categories to a person's disadvantage should not be permitted, even in formulations of probable cause. However, it becomes slightly more troubling when the officer's malignant purpose is removed and we move to a situation that resembles Yick Wo less and Washington v. Davis more. Assume that probable cause would otherwise objectively exist without the use of race, but that an officer, without an "evil eye" or "uneven hand," nonetheless uses race in part of his determination of probable cause. In other words, his motivation is simply to enforce the law; the racial categorization is a means, rather than an end. This moves us into the realm of subjective motivations, and it is in this realm that reliance upon the "could have" test becomes more problematic. Nonetheless, the outcome should be the same; just as an otherwise justifiable law would be found unconstitutional if it were used intentionally to disadvantage a person on the basis of skin color, so too would an otherwise reasonable search be deemed unreasonable if race was found to have informed that decision. In other words, given the enactment of the Fourteenth Amendment, the use of race should trump the existence of otherwise probable cause.

This is admittedly more troubling, for it risks becoming a stumbling block to any prosecution of any minority citizen, which in turn risks bringing about all of the costs described above. Fortunately, just as the Fourteenth Amendment supplies support for the notion that race is impermissible in a formulation of probable cause, so too does it limit the means of proving the existence of such uses of race. If officers admitted using race as a classification, the stop would automati- 
cally be treated as a governmental categorization based upon race and only be constitutional if the use of race was narrowly tailored to meet a compelling governmental interest. ${ }^{210}$ However, as claims became less blatant, and relied more and more upon evidence of a disparate impact to prove the violation, they would be subjected to the more exacting standards required of a disparate impact claim. ${ }^{211}$ Thus, the Court would minimize the risk of constant fishing expeditions into officers' minds (at least to any greater extent than would occur if subsequent litigation were brought, as the Whren Court suggests, under the Fourteenth Amendment).

While minimizing costs, such a rule would capture the benefits outlined above. By eliminating flagrant and open racial classifications, the Court would help to erode the second-class citizen status that racial profiling creates and, hopefully, would help to ease the psychological damages inflicted as well. ${ }^{212}$ This proposal would afford victims of racially motivated searches, who cannot achieve standing for declaratory relief, the protections of the exclusionary rule, and would also deter future violations. ${ }^{213}$ Indeed, this is exactly the type of police

210. See supra note 183. An example of a situation which might meet strict scrutiny is when a police officer is informed that a suspect in a particular crime is a member of a particular race. Under such circumstances, an officer may detain only members of that race. Of course, police officers must have sufficient additional information in their description to give rise to a sufficiently particularized suspicion. But if police officers are given a description of a 6'2" black male, wearing a Hawaiian shirt, with a scar on his face and a comb in his pocket, they are by no means required to ignore the racial cue, for it is a narrow solution to the government's interest in protecting its citizens. See, e.g., United States v. Valez, 796 F.2d 24, 26-27 (2d Cir. 1986) (holding that such a description of a defendant gave the officer probable cause for the arrest of that defendant).

211. See supra notes $116-18$ and accompanying text.

212. See supra notes $177-78$ and accompanying text.

213. One possible alternative would be to create an exclusionary rule for a violation of the Fourteenth Amendment. Indeed, one recent commentator has suggested just such a solution to the problem. See Lisa Walter, Comment, Eradicating Racial Stereotyping from Terry Stops: The Case for an Equal Protection Exclusionary Rule, 71 U. COLO. L. REV. 255, 258 (2000). However, the problems with this are twofold. First, it is unclear that the rationale supporting the Fourth Amendment exclusionary rule would support a violation of the Fourteenth Amendment. Indeed, the Court has been hesitant to apply the exclusionary rule to other types of constitutional violations. See, e.g., Michigan v. Harvey, 494 U.S. 344, 348 (1990) (implying that a Massiah violation carries no exclusionary rule); Maine v. Moulton, 474 U.S. 159, 188-90 (1985) (Burger, J., dissenting) (arguing that there should be no exclusionary rule for a Massiah violation); New York v. Quarles, 467 U.S. 649, 652-53 (1984) (O'Connor, J., concurring in part and dissenting in part) (suggesting that there is no exclusionary rule for a Miranda violation); see also Pamela S. Karlan, Race, Rights, \& Remedies in Criminal Adjudication, 96 MiCH. L. REV. 2001, 2010 (1998) ("As far as I can tell, with the exception of the two New Jersey state court cases that antedate Whren, there are no reported cases in which suppression was the remedy for racially selective enforcement.") (footnotes omitted). Indeed, creating such a rule would depend so 
misconduct that the exclusionary rule is crafted to deter. ${ }^{214}$

Such a rule would not be as revolutionary as it seems. Indeed, it would probably be more shocking to most Americans (and certainly to most African Americans) to learn that the use of race as even a partial basis for a search could be deemed "reasonable" under the Fourth Amendment. On a more doctrinal note, while totality-of-thecircumstances-style reasonableness is certainly the "touchstone of the Fourth Amendment," 215 per se rules are hardly unknown to the Fourth Amendment. For example, police may not enter homes without warrants, except in emergencies. ${ }^{216}$ Cars may be searched without a warrant if there is probable cause to do so. $^{217} \mathrm{~A}$ person may be searched incident to an arrest. ${ }^{218}$ The list goes on, but the basic idea is the same: certain actions are necessarily reasonable or unreasonable. Using race to create probable cause should be added to that list of actions.

\section{Answering Objections}

A number of objections could be made to this solution. First, it could be objected that adopting such a rule requires an unwarranted and, given the Court's current makeup, unlikely, activist departure from the Constitution's text. In a related argument, some might object that this is a problem properly left either to the legislature, or to the states and their courts. Finally, and at the other extreme, some would object that this approach is unduly narrow and would accomplish little. Each concern is addressed in order.

\footnotetext{
heavily on "Fourth Amendment causation principles," id. at 2009, that it is unclear exactly why we would not simply leave the rule grounded with the amendment with which it belongs.

Second, creation of such a rule would be a fairly revolutionary judicial invention; while it is by no means certain that a Fourth Amendment exclusionary rule is a constitutionally required—or even a good—idea, see Mapp v. Ohio, 367 U.S. 643, 678, 682-83 (1961) (Harlan, J., dissenting) (expressing doubt as to the constitutional origin of the exclusionary rule and its effectiveness), at least it has the benefit of being grounded in over eighty years of jurisprudence and tradition. See Weeks v. United States, 232 U.S. 383, 398 (1914) (establishing the exclusionary rule). By contrast, as I note below, it is wholly within the traditions of the Fourth Amendment, modified over 130 years ago by the Fourteenth Amendment, to incorporate norms of racial equality into our conceptions of a "reasonable" search and seizure.

214. See California v. Hodari, 499 U.S. 621, 646 (1991) (Stevens, J., dissenting) ("The deterrent purposes of the exclusionary rule focus on the conduct of law enforcement officers and on discouraging improper behavior on their part.").

215. United States v. Robinette, 519 U.S. 33, 39 (1996).

216. See Payton v. New York, 445 U.S. 573, 588-89 (1980).

217. See Carroll v. United States, 267 U.S. 132, 149 (1925).

218. See United States v. Robinson, 414 U.S. 218, 234-35 (1973).
} 
1. Activism. Rather than marking a recrudesence of Warren Court activism, a ruling that the Fourth Amendment's guarantee against unconstitutional searches and seizures recognizes Fourteenth Amendment equal protection values simply would bring the Fourth Amendment in line with longstanding precedent, with the language of both amendments, and with the traditions of our country. The Supreme Court has long held that the Fourteenth Amendment's guarantee of equal protection under the laws has modified other amendments to the Constitution. The most prominent example of such "reverse selective incorporation" has been the Court's application of the dictates of the Fourteenth Amendment to the Fifth Amendment's Due Process Clause. ${ }^{219}$ While this idea was made explicit by the Warren Court, it was by no means completely novel. Thirty-seven years prior to that decision, in Buchanan v. Warley, the Court relied upon equal protection analysis to unanimously strike down a state statute that denied the rights of a property owner to transfer property to a person of another race. ${ }^{220}$ However, although it used analysis commonly associated with the modern Court's equal protection analysis, the Buchanan Court did not find a violation of that clause. Rather, the Court noted that the norms of racial equality found in that clause pervaded other aspects of the Constitution; in this case, the Fourteenth Amendment's Due Process Clause. ${ }^{221}$ And twenty-one years before Buchanan, the Court summarized the emerging consensus embodied by the Fourteenth Amendment, eloquently proclaiming that

Underlying all of those decisions is the principle that the Constitution of the United States, in its present form, forbids, so far as civil and political rights are concerned, discrimination by the General Government, or by the States, against any citizen because of his race. All citizens are equal before the law. The guarantees of life, liberty and property are for all persons, within the jurisdiction of the United States, or of any State, without discrimination against any

219. See Bolling v. Sharpe, 347 U.S. 497, 499 (1954):

[T] he concepts of equal protection and due process, both stemming from our American ideal of fairness, are not mutually exclusive. The equal protection of the laws is a more explicit safeguard of prohibited unfairness than due process of law, and, therefore, we do not imply that the two are always interchangeable phrases. But, as this Court has recognized, discrimination may be so unjustifiable as to be violative of due process.

220. See Buchanan v. Warley, 245 U.S. 60, 78 (1917).

221. The Court there decided that the racial classifications in the statute were "in direct violation of the fundamental law enacted in the Fourteenth Amendment [prohibiting deprivations of property without] due process of law." Id. at 82 . 
because of their race. Those guarantees, when their violation is properly presented in the regular course of proceedings, must be enforced in the courts, both of the Nation and of the State, without reference to considerations based upon race. In the administration of criminal justice no rule can be applied to one class which is not applicable to all other classes. The safety of the race the larger part of which was recently in slavery, lies in a rigid adherence to those principles. Their safety-indeed, the peace of the country and the liberties of all-would be imperilled, if the judicial tribunals of the land permitted any departure from those principles based upon discrimination against a particular class because of their race. ${ }^{222}$

Similarly, the First Amendment incorporates Fourteenth Amendment equality norms, ${ }^{223}$ as does the Sixth Amendment's guarantee of an impartial jury. ${ }^{224}$

222. Gibson v. Mississippi, 162 U.S. 565, 591-92 (1896) (emphasis added). From one perspective, finding that due process incorporates norms of racial equality ends the story respecting the Fourth Amendment vis-à-vis the States. Technically speaking, a local or state police officer cannot violate the Fourth Amendment-that Amendment applies only to the federal government. See Miller v. Texas, 153 U.S. 535, 538 (1894) (holding that the Second and Fourth Amendments are only limitations upon the power of the federal government); Barron v. Mayor \& City Council of Baltimore, 32 U.S. (7 Pet.) 243, 250 (1833) ("These amendments contain no expression indicating an intention to apply them to the state governments."). Rather, a police officer violates the Fourth Amendment only inasmuch as the decisions behind the Fourth Amendment have been incorporated within our conceptions of the "due process of the law." See Wolf v. Colorado, 338 U.S. 25, 27-28 (1949) (applying the Fourth Amendment without the exclusionary rule to the states through the Due Process Clause); see also Mapp v. Ohio, 367 U.S. 643, 654-55 (1961) (overruling Wolf in part and applying the exclusionary rule to the states). Thus, all Bill of Rights violations by state and local officials are, in reality, due process violations; it is just that the law behind most of the provisions of the Bill of Rights is now considered part of due process of the law. See David E. Murley, Private Enforcement of the Social Contract: Deshaney and the Second Amendment Right to Own Firearms, 36 DUQ. L. REV. 827, 845 n.93 (1998) (listing the Second, Third, and Seventh Amendments, in addition to the Fifth Amendment's grand jury provision, as those that have not been incorporated); Robert J. Cottrol, Symposium, Structure, Participation, Citizenship, and Right: Lessons from Akhil Reed Amar's Second and Fourth Amendments, 87 GEO. L.J. 2307, 2324 n.83 (1999) (reviewing AKHIL REED AmAR, THE BILl of Rights: CREATION AND ReCONSTRUCTION (1998)) (listing the above guarantees with the addition of the Eighth Amendment's guarantee against unreasonable bail and failing to mention the Fifth Amendment's grand jury provision). Because, under clear Supreme Court precedent cited above, all due process conceptions have been guided by notions of equal protection, all constitutional violations technically claimed under the Due Process Clause are colored by similar concerns.

223. See Police Dep't of Chicago v. Mosley, 408 U.S. 92, $95-96$ (1972); Kenneth L. Karst, Equality as a Central Principle in the First Amendment, 43 U. CHI. L. REV. 20, 21 (1975) (calling for a "proper appreciation of the importance of the equality principle in the first amendment").

224. See Turner v. Murray, 476 U.S. 28, 36-37 (1986) (holding that because the risk of racial prejudice may have affected his capital sentencing, the Sixth Amendment's guarantee of an impartial jury entitled a black defendant accused of capital murder involving an interracial crime the right to inform prospective jurors of the race of the victim and to question those jurors on the issue of racial bias). See generally JOHN HART ElY, DEMOCRACY AND DisTRUST (1980) (explaining that the Sixth Amendment incorporates Fourteenth Amendment equality norms). 
However, incorporating these norms into the law of the Fourth Amendment would not even require the Court to engage in such mental acrobatics as squeezing the Equal Protection Clause into the oxymoron known as "substantive due process." While it is easy to object that due process cases were wrongly decided, since the Due Process Clause excludes (or should exclude) non-procedural considerations, ${ }^{225}$ the text of the Fourth Amendment is different. The term "reasonableness" is of its very essence the type of "weasel word" that is open to judicial interpretation and sensitivity to changing times (and that is also left out of most other dictates of the Bill of Rights). ${ }^{226}$ For example, the whole field of "special needs" searches involves instances in which the particularity and probable cause requirements are waived altogether in order to ensure that the "reasonability" of searches outside the needs of law enforcement are kept in line with the changing needs of society. ${ }^{227}$ And even if one discounts the Court's recent drift away from "probable cause" as the touchstone for reasonability, ${ }^{228}$ there is still ample support for the proposition that findings of probable cause are governmental classifications that should be

225. See, e.g., ROBERT BORK, THE TEMPTING OF AMERICA 31-32 (1990) (criticizing Bolling and other substantive due process cases).

226. "Weasel words" are words that, because of their imprecise nature, afford judges such discretion as to render a phrase meaningless. See Holyoke Water Power Co. v. American Writing Paper Co., 300 U.S. 324, 336 (1937) ("The fact is of little moment that currency is characterized as a commodity in the verbiage of the covenant as long as it is currency. Weasel words will not avail to defeat the triumph of intention when once the words are read in the setting of the whole transaction.") (citation omitted); see also Don Mayer, Workplace Privacy and the Fourth Amendment: An End to Reasonable Expectations?, 29 AM. BUS. L.J. 625, 656-57 (1992) (describing "unreasonable" as "the negative counterpart to "the greatest weasel-word in the legal lexicon"' (quoting F. Hodge O'Neal, Remarks at Duke University School of Law (Sept. 1970))); Michael Stokes Paulson, A RFRA Runs Through It: Religious Freedom and the U.S. Code, 56 MONT. L. REV. 249, 289 (1995) (classifying an admonition "generally" not to apply a test as including a weasel word); Gary D. Rowe, Lochner Revisionism Revisited, 24 L. \& SOC. INQUIRY 221, 240 (1999) (characterizing "reasonable" and "arbitrary" as "weasel words" for constitutional purposes). Indeed, it is the lack of "weasel words" such as "reasonable" that, at least in part, led Justice Black to his absolutist position on the First Amendment. See Beauharnis v. Illinois, 343 U.S. 250, 274-75 (1952) ("I think the First Amendment, with the Fourteenth, 'absolutely' forbids such laws without any 'ifs' or 'buts' or 'whereases.') (Black, J., dissenting); Charles A. Reich, Mr. Justice Black and the Living Constitution, 76 HARV. L. REV. 673, 716-17 (1963) (describing Justice Black's acceptance of balancing in certain areas and aversion in others).

227. See, e.g., Skinner v. Railway Labor Executives' Ass'n, 489 U.S. 602, 619 (1989) (“When faced with such special needs, we have not hesitated to balance the governmental and privacy interests to assess the practicality of the warrant and probable-cause requirements in the particular context.").

228. See Wyoming v. Houghton, 526 U.S. 295, 295 (1999) (citing the standard for reasonability as the "common law when the [Fourth] Amendment was framed"). 
subjected to strict scrutiny under the Fourteenth Amendment. ${ }^{229}$ In any event, the Fourth Amendment's ban on "unreasonable" searches is much like the Eighth Amendment's prohibition against "cruel and unusual" punishments, a prohibition that also incorporates Fourteenth Amendment law, ${ }^{230}$ and that even the most textualist of Justices has held, reflects, to a certain extent, conventional mores. ${ }^{231}$

This is not at all to say that Justices should be allowed to run roughshod over the language of the Fourth Amendment and find in it completely atextual rights. As reflected in Eighth Amendment jurisprudence, there are ways to limit a judge's-or Justice's-discretion to interpret these Clauses loosely. ${ }^{232}$ Ultimately though, by relying upon the text of the Fourteenth Amendment for its grounding, the proposal is somewhat insulated from these criticisms; for better or for worse, the ban upon use of racial categorizations to a person's disadvantage is frankly commanded by the Constitution.

In light of this, it would hardly be a hallmark of judicial activism for the Court to hold that even partially race-based stops are "unreasonable" under the Fourth Amendment. Indeed, doing so may effectuate the original understanding of the Fourth Amendment in light of

229. See supra notes 207-10 and accompanying text.

230. In McCleskey, the Supreme Court seemed to imply that, had McCleskey proved racial discrimination, it would have been sufficient to sustain an Eighth Amendment claim. See McCleskey v. Kemp, 481 U.S. 279, 305-12 (1987). Indeed, in McCleskey v. Kemp, 753 F.2d 877 (11th Cir. 1985), the Eleventh Circuit noted:

As the district court here pointed out, such a standard indicates an analytical nexus between Eighth Amendment claims and a Fourteenth Amendment equal protection claim. Where an Eighth Amendment claim centers around generalized showings of disparate racial impact in capital sentencing, such a connection is inescapable. Although conceivably the level or amount of disparate racial impact that would render a state's capital sentencing system arbitrary and capricious under the Eighth Amendment might differ slightly from the level or amount of disparate racial impact that would compel an inference of discriminatory intent under the equal protection clause of the Fourteenth Amendment, we do not need to decide whether there could be a difference in magnitude that would lead to opposite conclusions on a system's constitutionality depending on which theory a claimant asserts. A successful Eighth Amendment challenge would require proof that the race factor was operating in the system in such a pervasive manner that it could fairly be said that the system was irrational, arbitrary and capricious.

Id. at 891 (citation omitted); see also Furman v. Georgia, 408 U.S. 238, 257 (1972) (Douglas, J., concurring) (arguing that the ideal of equal protection of the laws is "implicit in the ban on 'cruel and unusual' punishments"); ELY, supra note 224, at 97 ("The Eighth Amendment's ban on 'cruel and unusual punishments' is even more obviously amenable to this account [of ending arbitrary judgments in a similar vein as the Equal Protection Clause].").

231. See Stanford v. Kentucky, 492 U.S. 361, 369 (1989) (Scalia, J.) (relying upon prior holdings that, when interpreting "evolving standards of decency," the Court should look "not to our own conceptions of decency, but to those of modern American society as a whole").

232. For a description of various limits the Court has imposed upon interpretations of "cruel and unusual" punishments, see Stanford, 492 U.S. at 369-71. 
the Fourteenth Amendment. The purpose of the Fourth Amendment is to protect against the arbitrary invasions of rights, just as the Fourteenth Amendment protects against inequitable treatment under the law. ${ }^{233}$ Given this, the solution proposed could be seen as just another in a long series of "unceasing efforts to eradicate racial prejudice from our criminal justice system.",234

2. Profiling is Properly for the States or Legislature. In many ways, by demonstrating a commitment to equality norms in the Fourth Amendment, this argument is largely defeated. The Fourteenth Amendment inarguably transferred the primary responsibility for protection of the constitutional guarantees of United States citizens to the federal government; indeed, the Court's longstanding approval of section 1983 demonstrates the appropriate federal role in civil rights enforcement ${ }^{235}$ this is ultimately a federal problem.

Moreover, although legislative responses are particularly desirable, especially given that an unworkable congressional decision is more easily repealed than a judicial one ${ }^{236}$ most of the congressional solutions that have been suggested are not particularly feasible. For example, Vice President Gore has promised that the first civil rights act of the twenty-first century, under his administration, would be a law to end racial profiling "in insurance and in banking, inside school rooms and inside people's hearts." ${ }^{237}$ However, the difficulty of enacting a law to change anything in people's hearts is one of the major limiting factors of any system of laws.

233. See ELY, supra note 224, at 97 ("[T] he Fourth Amendment can be seen as another harbinger of the Equal Protection Clause, concerned with avoiding indefensible inequities in treatment.").

234. McCleskey, 481 U.S. at 309 (quotations omitted).

235. This "federalism exception" for federal civil rights legislation is perhaps best illustrated by the exception to the Eleventh Amendment that is carved out for the enforcement of legislation enacted in pursuit of the Fourteenth Amendment. See Fitzpatrick v. Bitzer, 427 U.S. 445, 456 (1976) ("Congress may ... for the purpose of enforcing the provisions of the Fourteenth Amendment, provide for private suits against States or state officials which are constitutionally impermissible in other contexts.").

236. See Crump, supra note 45 , at 329-30.

237. See Ian Christopher McCaleb \& Amy Paulson, Gore, Bradley Lock Horns over Legislative Records, at http://cnn.com/2000/ALLPOLITICS/stories/02/22/apollo.debate/ index.html (last visited Feb. 23, 2000) (on file with the Duke Law Journal). 
The most commonly discussed legislative solution-enactment of the Traffic Stops Statistics Act ${ }^{238}$ - suffers similar shortcomings. This Act would require officers to keep various data for every traffic stop initiated, including the race and age of the person stopped, whether a search resulted, whether the search was successful, and why the officer made the stop. ${ }^{239}$ This would allow the federal government to gauge the depth of racial profiling throughout the country.

However, this solution would accrue most of the costs described in section III.A and almost none of the benefits. Indeed, it is unclear exactly what benefits the Act would bring, since the data collected would not reveal the race of the arresting officer or the location of the stops, could not be used for the purposes of litigation, ${ }^{240}$ and might actually have the perverse effect of reversing training designed to discourage officers from "seeing" race. ${ }^{241}$

238. One interesting alternative that has been put forth, but which cannot be fully discussed in the interest of space, is the possibility of actually incorporating racial awareness into policing and our sentencing laws. For example, Paul Butler suggests that to balance the disproportionate numbers of blacks in the criminal justice system, affirmative action concepts should be incorporated into the criminal law. See Paul Butler, Affirmative Action and the Criminal Law, 68 U. COLO. L. REV. 841, 844 (1997). Butler begins with the question "What does America owe the black criminal?", and concludes with a litany of legislative responses, including provisions that "African American criminal defendants shall have the right to majority black juries" and that "[e]very jurisdiction in the United States shall maintain, by the year 2000, a prison population that accurately reflects the racial diversity of the jurisdiction." Id. at 859,877 . Butler suggests achieving this goal not necessarily by letting the worst African-American criminals out, but rather by adding more white criminals, such as "tobacco distributors ... manufacturers of unsafe automobiles and airplanes" and those who engage in hate speech. Id. at 869.

As an interesting thought experiment, assume, for the moment, that Butler's argument is true: that much, if not most, of black crime is committed as a legacy of slavery. But $c f$. THOMAS SOWELL, VISION OF THE ANOINTED 79-81 (1995) (describing-and disparaging - the notion that the "legacy of slavery" has affected the current status of blacks to a significant extent). However, rather than asking, as Butler does, "What does America owe the black defendant?" suppose we ask, as Randall Kennedy might, "What does America owe the black crime victim?" This would lead to a very different, even possibly inverted, policy from that proposed by Butler. Given that blacks are disproportionate victims of crime-especially of intraracial crime, see supra notes 174-76 and accompanying text—one could envision profiling enacted as an affirmative action solution in inner cities. Such a program could conceivably pass constitutional muster under Regents of the Univ. of Cal. v. Bakke, 438 U.S. 265 (1978), if it were narrowly tailored to neighborhoods where blacks were disproportionately the victims of crime, since, given Butler's argument, such a program could be justified as a remedial measure for an enduring legacy of slavery.

The obvious rejoinder to all this is that in Bakke, the "victim" category was made up of whites, whereas under the above-described program, both the victims and the beneficiaries would be black. My point is not to suggest (at all) that such a program would be desirable. Rather, it is to illustrate the dangers in incorporating racial awareness into the criminal law.

239. See Russell, supra note 8, at 726.

240. See id. at 726-27.

241. See id. 
Also, the data collected may well be of dubious value. Because there is essentially no enforcement mechanism, nothing is to preclude an officer from fabricating the race of the driver. Indeed, this seems to be the likely response for the "rogue cops" the Act is trying to stop. Thus, aside from increasing the ammunition for racial demagogues, and possibly improving the hands of some plaintiffs in forcing settlements in suits against political figures, it is unclear that the Traffic Stops Statistics Act will advance the cause of ending racial profiling to any appreciable degree. ${ }^{242}$

Given this, potential costs to the Act become even more important. It seems likely that, under the Act, an officer would become more conscious of the race of drivers whom he pulls over. On one hand, this increased consciousness could be good: perhaps an officer would uncover his own unconscious racism and correct unintentional profiling. On the other hand, one can easily imagine a scenario where an officer encounters some "statistical noise"; a blurb of four AfricanAmerican speeders in a row pass by him, or three stops out of five reveal African Americans who display indicia of drug couriers, while the other two turn up Caucasian drivers who do not fit the profile. Such "runs" are familiar to any student of statistics, and if a police officer pulls over a relatively small number of motorists in a given month (fewer than 500 or so), such runs can badly distort his true propensity to stop and search minority drivers. A significant social cost could be extracted if a police officer who normally would have searched the third minority driver in that situation did not, especially if that driver were carrying contraband. This possibility seems especially likely if Bernard Parks and others are correct that blacks disproportionately courier drugs in a particular are $\mathrm{a}^{243}$-an officer examining that area using no profile whatsoever would find herself pulling over disproportionate numbers of minority motorists. If the Traffic Stops Statistics Act would produce monumental change, these potential costs would be worth bearing. Because the Act would do little to improve the status of minority motorists, however, such costs seem unacceptable.

242. One possible use for the Act is the identification of "rogue cops." If the percentage of minority motorists stopped by one officer is hugely disproportionate to the rest of the police force, the Traffic Stops Statistics Act would identify that officer, and allow appropriate action to be taken. However, as I noted above, since these are the individuals who are probably the most likely to fabricate their data, it is unclear how much the Act would aid in deterring them.

243. See supra notes $154-60$ and accompanying text. 
Thus, while legislative solutions are tempting on their face, upon closer examination, they are problematic. Most solutions would be ineffective, and would extract a significant toll. At the very least, there seems to be a role for both branches-the Court should hold that probable cause cannot be based upon race irrespective of whether Congress acts further.

3. The Solution Does Too Little. To be sure, the suggestion offered is imperfect. It would affect only those cases where a police officer admits to pulling over African Americans due to their race, or where the statistics are so compelling that there can simply be no other rational explanation for the stop. And it may well be that the largest effect of the suggested approach would be to drive racism underground; officers may well concoct convincing post hoc rationalizations for their missteps. But even this small step could be beneficial; even if the Civil Right Act of 1964 did nothing other than ensure that signs reading "[African Americans] need not apply" disappeared from the American landscape, it would still have been a huge step. Similarly, by eliminating the most blatant uses of racial categorizations from traffic stops, the proposal would eliminate what is perceived by many as an existing stamp of second-class citizenship for African Americans.

If nothing else, this proposal represents a reasonable first step. However, as we step further, we should constantly be mindful of the need for carefully examining the costs and benefits of solutions; because the problem is so difficult to solve effectively, all solutions have the potential of creating more problems than they solve. And we must always, as explained above, tread lightly, since the costs of an overbroad profiling law are likely to be borne by those whom such a law is meant to protect. ${ }^{244}$ Hearts must be changed with persuasion; the fundamental correctness of racial equality has always been its strongest asset-neither slavery nor Jim Crow were eliminated due to utilitarian calculations-and minds eventually will change on this issue. In the meantime, this is a situation where a correct interpretation of the Constitution has the added benefit of simply being morally correct even if there is little practical effect; the Court should take advantage of this opportunity. 


\section{CONCLUSION}

The bottom line seems to be that, for all practical intents and purposes, if one brings a suit alleging racial profiling, one should expect to lose, and to lose early in the process. Courts have erected very high barriers for satisfying the threshold of standing. Moreover, the obvious recourses-suits under section 1983 for violations of Fourth or Fourteenth Amendment rights-have not proved fruitful in the courts. Even if these hurdles are overcome, courts have held that police may, in fact, legally use race as part of a decision to detain a suspect. In short, no immediate remedy currently appears to be available for the unlucky motorist who is pulled over on the basis of his race. Given the number of racial profiling cases working their way up through the courts of appeals, the Supreme Court will undoubtedly have ample opportunity to reexamine the problem over the next few years. Whren represents the Court's first pronouncement on the intersection between race and probable cause. It is not likely to be the last. 